\title{
STRONTIUM AND CALCIUM METABOLISM IN METABOLIC BONE DISEASES *
}

\author{
By ELIAS C. DOW AND JOHN B. STANBURY \\ (From the Medical Services of the Massachusetts General Hospital and the Department of \\ Medicine of the Harvard Medical School, Boston, Mass.)
}

(Submitted for publication September 9, 1959; accepted February 19, 1960)

Skeletal and systemic disease may be reflected in profound alterations of the metabolism of the bone salts. In human skeletal disease attention has focused, for the most part, on the altered metabolism of calcium. Several studies indicate that strontium may have a metabolic pathway similar to that of calcium and that radiostrontium, because of its ease of measurement, might be a convenient indicator for observing the transfer of calcium through the calcium-containing compartments of the body.

The investigations to be reported here are concerned with the comparative distribution and fate of calcium and strontium in subjects with altered bone metabolism. Patients with thyroid and parathyroid disease, osteoporosis, and Paget's disease were studied after simultaneous intravenous administration of strontium ${ }^{85}$ and calcium ${ }^{45}$. The results indicate that $\mathrm{Sr}^{85}$ closely parallels $\mathrm{Ca}^{45}$ as an index of skeletal function.

\section{MATERIALS AND METHODS}

All patients (Table I) were on the Metabolic Research Ward, were ambulatory throughout the study, and spent a few hours out of doors each day with a nurse in attendance. Each received a constant neutral ash diet containing 88 to $206 \mathrm{mg}$ of calcium per day (Table II). The calculated daily magnesium intake did not exceed $200 \mathrm{mg}$. Fluid intake was kept between 2,000 and $2,500 \mathrm{ml}$ per day. After a minimum of 7 days on the fixed diet, a 3-day control collection of urine and feces was obtained before administration of the labeled isotopes.

The dose of labeled calcium and strontium was prepared from hydrochloric acid stock solutions of $\mathrm{Ca}^{45} \mathrm{Cl}_{2}{ }^{1}$ of high specific activity, and from carrier-free $\mathrm{Sr}^{85} \mathrm{Cl}_{2}{ }^{2}$

* This work was done under Atomic Energy Commission Contract AT(30-1)-1755.

1 Obtained from Oak Ridge. $\mathrm{Ca}^{\text {ts }}$ emits only beta rays of $0.100 \mathrm{Mev}$ average energy and has a half-life of 163 days.

2 Produced by Nuclear Science and Engineering Corp., Pittsburgh, $\mathrm{Pa}$. $\mathrm{Sr}^{85}$ is a pure gamma emitter of 0.513 $\mathrm{Mev}$ and has a half-life of 65 days.
Predetermined amounts of each isotope were measured into separate bottles and saline added so that concentrations of $1 \mu \mathrm{c} \mathrm{Ca}{ }^{45}$ per $\mathrm{ml}$ and $2.5 \mu \mathrm{c} \mathrm{Sr}^{85}$ per $\mathrm{ml}$ were obtained. Equal volumes of each of these solutions were combined to give a final solution containing 0.5

TABLE I

Clinical data

\begin{tabular}{|c|c|c|c|}
\hline Name & Age & $\operatorname{Sex}$ & Diagnosis \\
\hline W.B. & 53 & $\mathbf{M}$ & $\begin{array}{l}\text { Hyperthyroid (diffuse goiter) } \\
\text { (Thyrotox.*) }\end{array}$ \\
\hline $\begin{array}{l}\text { J.H. } \\
\text { J.C. (I) }\end{array}$ & $\begin{array}{l}42 \\
65\end{array}$ & $\begin{array}{l}\mathrm{F} \\
\mathrm{M}\end{array}$ & $\begin{array}{l}\text { Myxedema (Myx.) } \\
\text { Myxedema (Myx.) }\end{array}$ \\
\hline J.C. (II) & 65 & $\mathbf{M}$ & $\begin{array}{l}\text { Euthyroid ( } 4 \text { months on thy- } \\
\text { roid } 120-150 \mathrm{mg} \text { q.d.) (Nor- } \\
\text { mal after } \mathrm{Rx} \text { ) }\end{array}$ \\
\hline E.H. & 59 & $\mathrm{~F}$ & $\begin{array}{l}\text { Follicular adenocarcinoma of } \\
\text { thyroid, metastatic to lungs } \\
\text { and left pelvic bones and } \\
\text { hip (Met. thyroid Ca) }\end{array}$ \\
\hline M.S. & 38 & $\mathrm{~F}$ & $\begin{array}{l}3 \text { Years after hemithyroidec- } \\
\text { tomy for nontoxic nodular } \\
\text { goiter (Euthyroid) }\end{array}$ \\
\hline J.W. & 72 & $\mathbf{M}$ & $\begin{array}{l}\text { Hyperparathyroid; diabetes } \\
\text { mellitus; myocardial infarct; } \\
\text { pyelitis and ? renal stone } \\
\text { (Hyperparathyr.) }\end{array}$ \\
\hline A.L. & 31 & M & $\begin{array}{l}\text { Progressive idiopathic osteo- } \\
\text { porosis (parathyroid ex- } \\
\text { ploration negative) (Osteo- } \\
\text { porosis) }\end{array}$ \\
\hline L.L. (I) & 77 & $\mathrm{~F}$ & Chronic osteoporosis (2 year \\
\hline
\end{tabular}
on estrogen therapy) (Osteoporosis on $\mathrm{Rx}$ )

L.L. (II) $\quad 77 \quad$ F $\quad$ Chronic osteoporosis (4 months off therapy) (Osteoporosis off $\mathbf{R x}$ )

E.S. $\quad 67 \quad F \quad$ Osteitis deformans involving (by $\mathrm{X}$-ray) skull, pelvis and thoracic spine (Paget's)

A.J. (I) $64 \quad$ M

Osteitis deformans, extensive, involving skull, spine, pelvis and lower extremities (Paget's)

A.J. (II) $64 \quad \mathrm{M}$ Osteitis deformans, on cortisone acetate $300 \mathrm{mg}$ q.d. (Paget's on cortisone)

A.J. (III) $65 \quad M \quad$ Osteitis deformans, on no therapy for 5 months (Paget's)

* Abbreviations are those used in subsequent tables. 


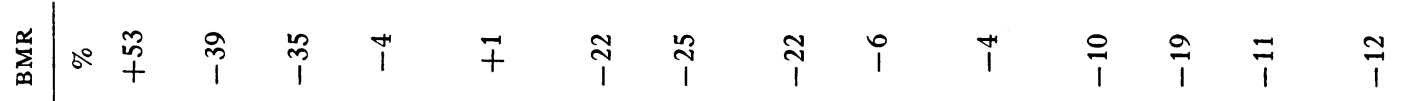

|

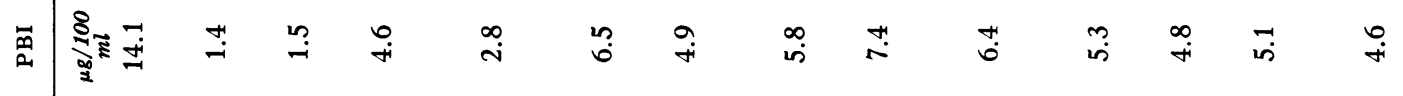
离

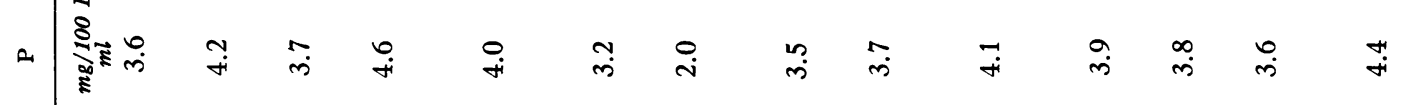

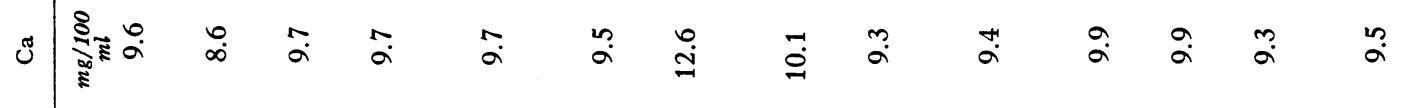
事蒂

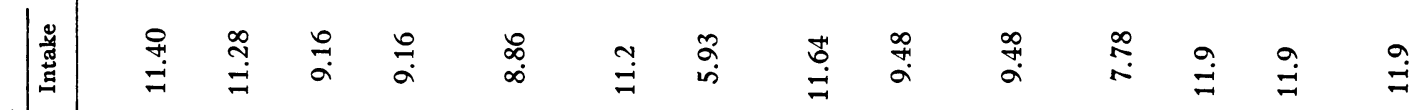

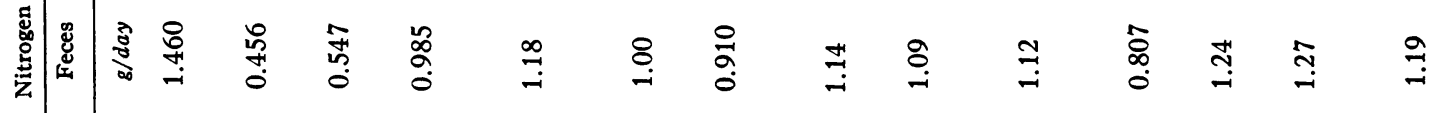

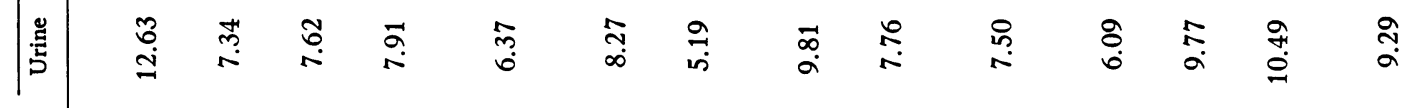

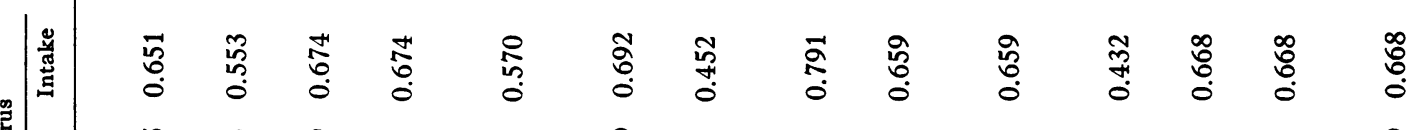

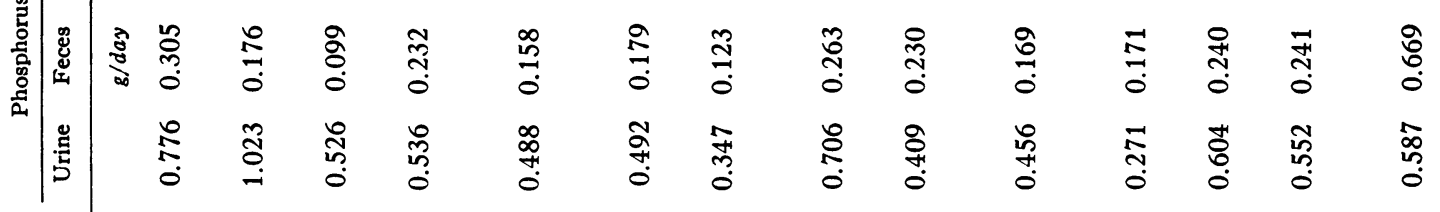

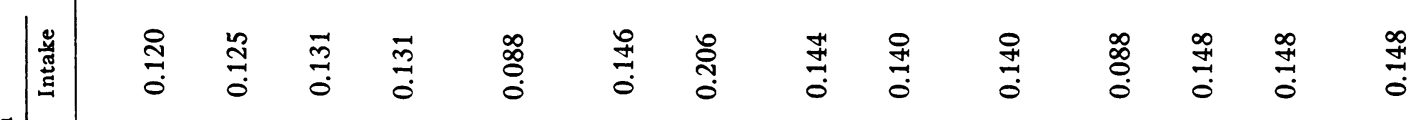

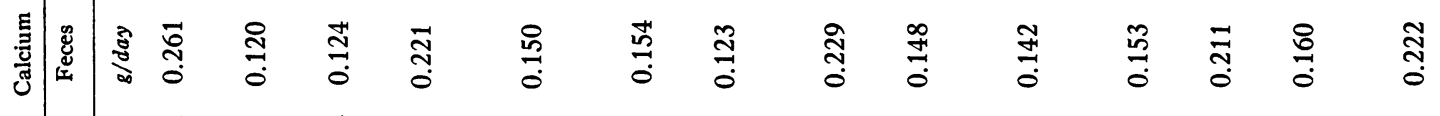

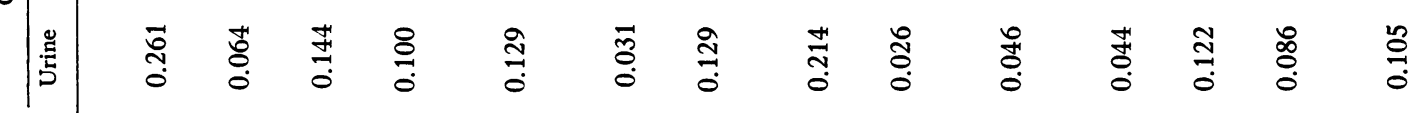

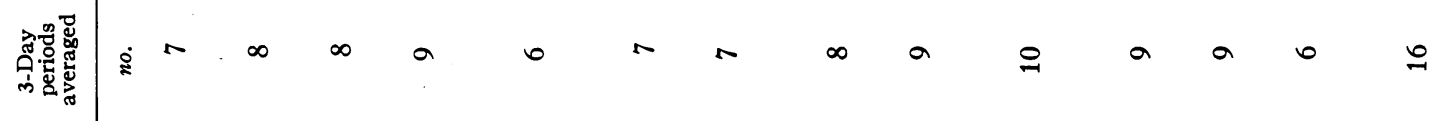

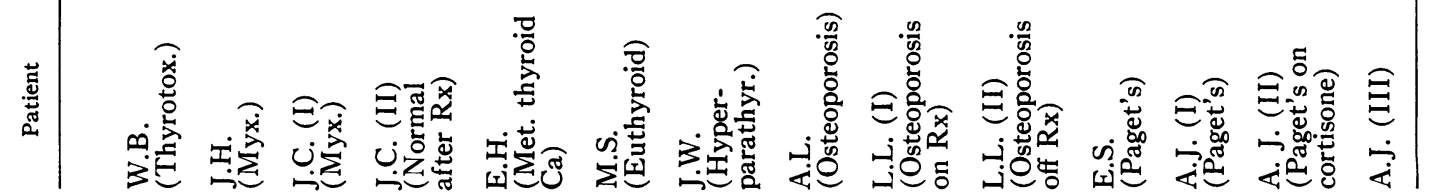


$\mu \mathrm{c}$ of $\mathrm{Ca}^{45}$ and $1.25 \mu \mathrm{c} \mathrm{Sr}^{85}$ per $\mathrm{ml}$. Thus, the administered $10 \mathrm{ml}$ dose delivered a total of $5 \mu \mathrm{c} \mathrm{Ca}{ }^{45}$ and 12.5 $\mu \mathrm{c} \mathrm{Sr}^{85}$. Patients for whom only one study was intended were given double these amounts in the same volume. The stable calcium $\left(\mathrm{Ca}^{40}\right)$ in each dose varied from 1 to $4 \mathrm{mg}$.

The prescribed dose was injected from a calibrated syringe into an antecubital vein 2 hours before breakfast. Blood samples were obtained by venipuncture from the opposite arm at 5 and 30 minutes, 1, 2, 4, 6, 8, 12,16 and 32 hours, and daily thereafter. Urine collections were made at 0 to 2,2 to 4 and 4 to 8 hours, and at 8 -hour intervals thereafter until the third day, when 24-hour collections were begun. Stool collections were made without a marker in 3-day periods. Except as indicated, each patient was studied for a minimum of 21 days.

Metabolic balances for stable calcium, phosphorus and nitrogen were measured according to methods previously described (1). All determinations for calcium were performed in duplicate on 2 different aliquots of each specimen.

Isotopic measurements. Since all samples contained both $\mathrm{Ca}^{45}$ and $\mathrm{Sr}^{85}$ in varying quantities, the following method was employed to determine the amount of each isotope in each specimen.

$\mathrm{Sr}^{83}$ was measured directly in a well-type scintillation counter equipped with a pulse-height analyzer. This apparatus had a background of $8 \mathrm{cpm}$, a counting effciency of 16.4 per cent for $\mathrm{Sr}^{85}$ (sensitivity $=360,000$ cpm per $\mathrm{mc}$ ), and completely excluded radiation from $\mathrm{Ca}^{45}$. Duplicate samples of $2 \mathrm{ml}$ of serum, acidified urine, and redissolved stool ash were measured for 10 minutes and compared with standards made up from the same $\mathrm{Sr}^{85}$ solution as that used for the administered dose. There was a statistical counting error of 2 per cent, except for specimens from the latter phases of each study, when the probable error of measurement of $\mathrm{Sr}^{85}$ was as high as 6 per cent.

Specimens for the determination of $\mathrm{Ca}^{45}$ were prepared by a modification of the method of Maletskos (1). It was repeatedly found that the $\mathrm{Sr}^{85}$ present, as well as the $\mathrm{Ca}^{45}$, was completely recovered on the planchets. These planchets, containing both $\mathrm{Ca}^{45}$ and $\mathrm{Sr}^{85}$, were counted in a gas-flow counter (SC-50 Tracerlab) which had an efficiency of 20.9 per cent (sensitivity $=460,000$ cpm per $\mathrm{mc}$ ) for $\mathrm{Ca}^{45}$ and only 1.46 per cent for $\mathrm{Sr}^{85}$ (sensitivity $=32,000 \mathrm{cpm}$ per $\mathrm{mc}$ ). Duplicate planchets

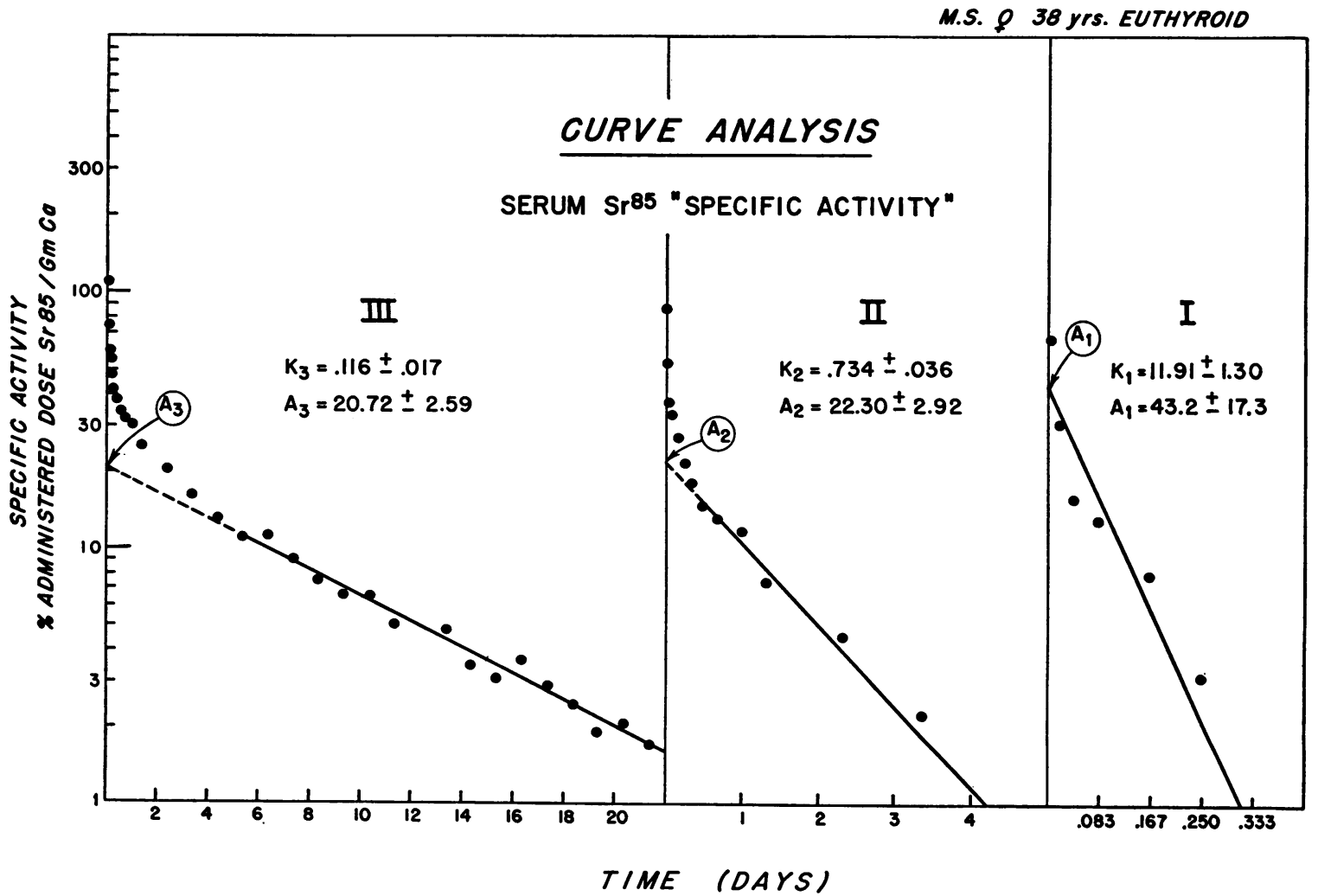

Fig. 1. Illustration of THE LINE REgRession METhod of ANALYSis APPLIED to CA ${ }^{45}$ AND SR ${ }^{85}$ URINE AND SERUM SPECIFIC ACTIVITy CURVES of ALL SUBJects studied. The solid lines were fitted to the data by method of least squares, have a slope, $k$, and when extrapolated to zero time yield the respective coefficients, A. Note the different time scale for III, II and I. Since the rate constants represent negative slopes, the value of $k$ is negative. 
of each specimen were measured for a total of 4,000 counts each three times over. Each run also included standards of $\mathrm{Ca}^{45}, \mathrm{Sr}^{85}$, and a standard of $\mathrm{Ca}^{45}$ and $\mathrm{Sr}^{85}$ made up directly from the administered dose.

When both labeled isotopes were measured in the gasflow counter, it was necessary to apply a correction for the $\mathrm{Sr}^{85}$ in order to obtain a true value for $\mathrm{Ca}^{45}$. From the total $\mathrm{Sr}^{85}$ counts per specimen in the well counter and from the counting efficiency of the gas-flow counter for $\mathrm{Sr}^{85}$, the counts from the gas-flow counter due to $\mathrm{Sr}^{85}$ alone could be calculated. A decay factor was employed when samples of the same specimens were counted in the respective machines on different days. Subtracting the $\mathrm{Sr}^{85}$ counts from the total counts of each sample provided the counts due to $\mathrm{Ca}^{45}$. A control on this method was made with every set of experimental samples. Predicted values of $\mathrm{Sr}^{85}$ standards varied less than 5 per cent from the observed counts in the gas-flow counter. Likewise, the calculated radioactivity due to $\mathrm{Ca}^{45}$ in standards containing both isotopes was within 3 per cent of the measured radioactivity of standards containing $\mathrm{Ca}^{45}$ alone.

Concentrations of each labeled isotope were expressed as per cent administered dose per unit volume. Specific activity was expressed as per cent administered dose per gram of calcium. Since there were only trace amounts of strontium in the specimens analyzed, stable strontium was not determined. The "specific activity" of $\mathrm{Sr}^{\mathbf{8 5}}$ was calculated as per cent administered dose of $\mathrm{Sr}^{85}$ per gram of calcium.

\section{Methods of analysis}

In each case study, $\mathrm{Ca}^{45}$ and $\mathrm{Sr}^{85}$ data were analyzed separately. Urine and serum specific activities were plotted semilogarithmically against time. Inspection of these curves suggested resolution into at least 3 exponential functions, each function possibly related to a discrete calcium compartment within the body. The term "compartment" is used to indicate a functional unit, but not necessarily an anatomical one. The method of curve analysis has been described elsewhere (1). The line regression method of Snedecor (2) was used and is illustrated in Figure 1. Each curve was analyzed in the form:

$$
\text { specific activity }=\mathrm{A}_{1} \mathrm{e}^{-\mathrm{k}_{1} t}+\mathrm{A}_{2} \mathrm{e}^{-\mathrm{k}_{2} t}+\mathrm{A}_{3} \mathrm{e}^{-\mathrm{k}_{3} t} \text {. }
$$

In an analysis of a theoretical multicompartmented system the coefficient of each term, A, is a composite of the compartment size of each component of the system. Similarly the rate constant, $\mathrm{k}$, is a composite term. If the assumption is made that compartment sizes and turnover times increase sequentially by an order of magnitude, then the coefficients and rate constants approximate those which actually obtain. Thus, the constants shown in the equation above hold as approximations, and rate constants and compartment sizes (I, II, and III) can be calculated (1).

Calcium "pool." The "pool" of calcium is defined as :

per cent isotope retained in the body at time, $\mathrm{t}$

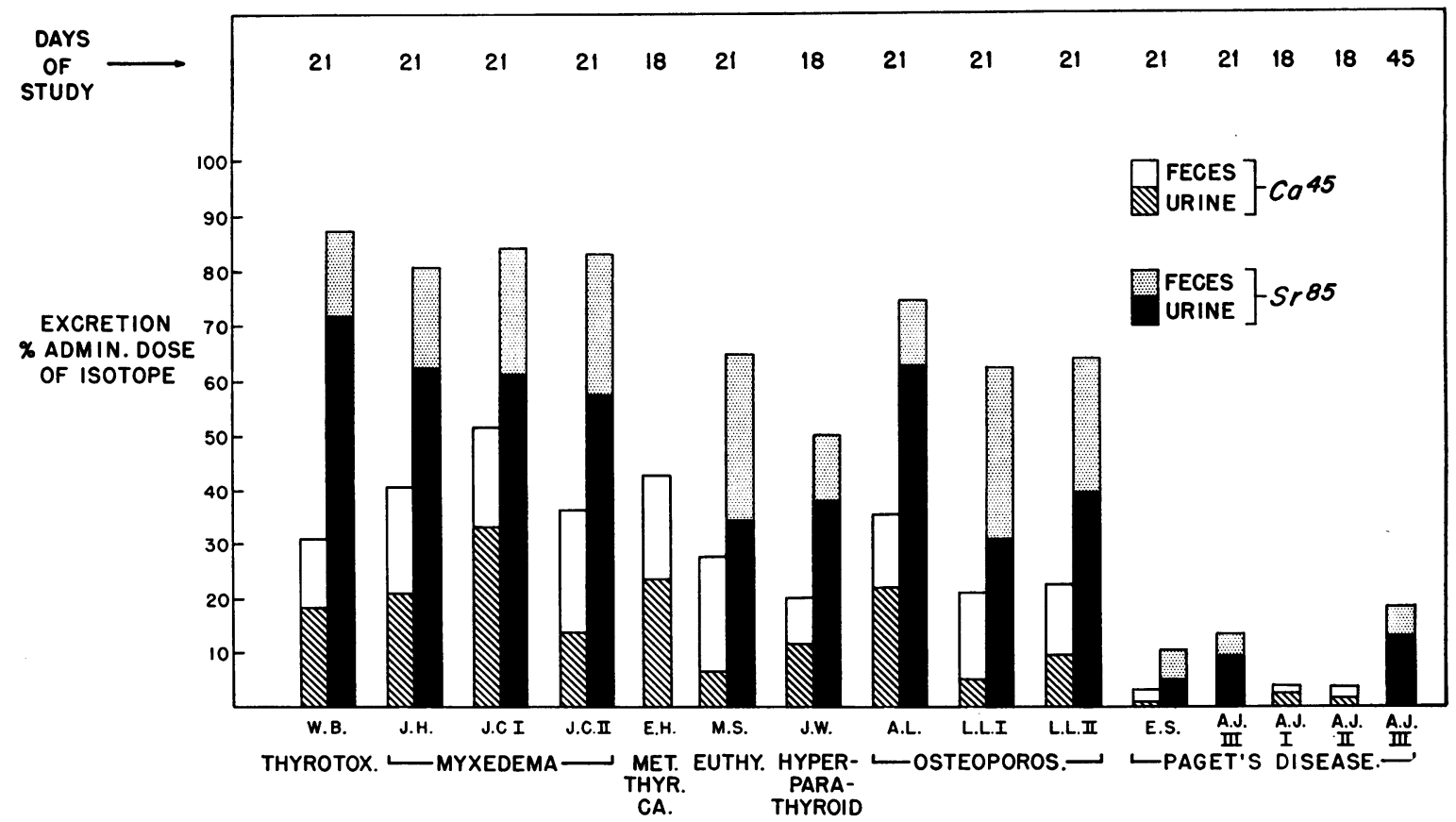

Fig. 2. Diagrammatic plot of total $\mathrm{CA}^{45}$ AND $\mathrm{SR}^{85}$ excreted at times indicated. Whole body retention in each case can be easily judged by subtracting the total excretion of each isotope from 100 per cent, the administered dose. 
STRONTIUM AND CALCIUM METABOLISM IN BONE DISEASES

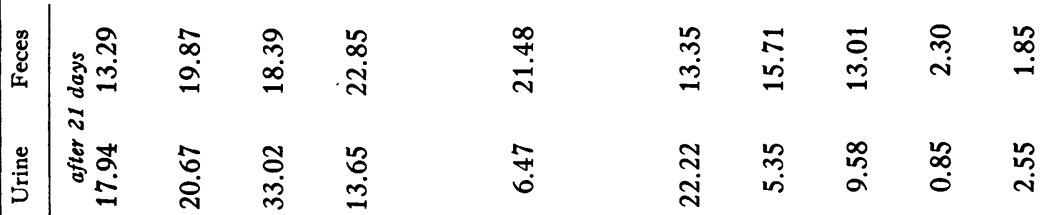

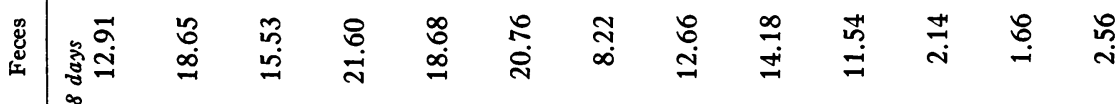

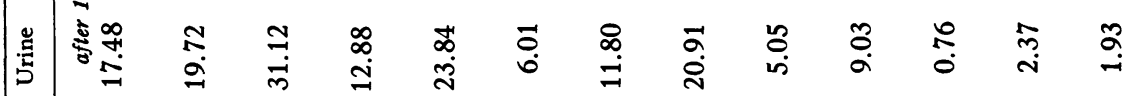

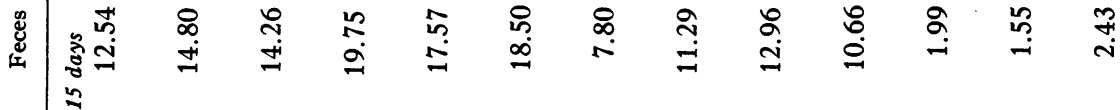

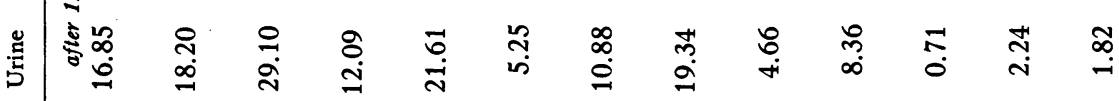

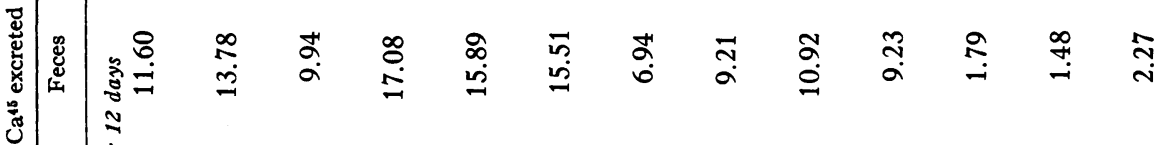

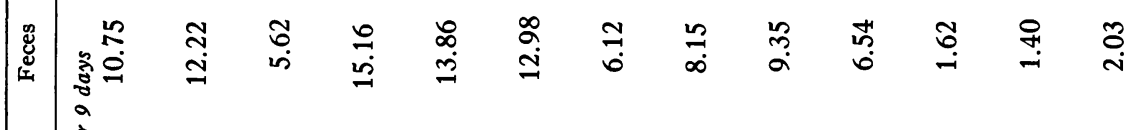

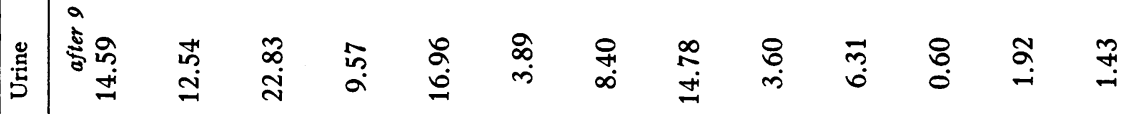

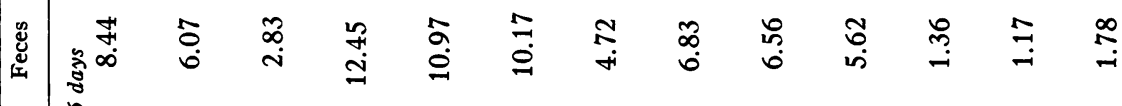

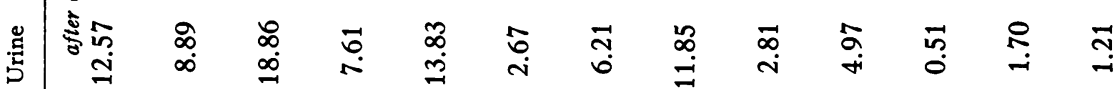

总

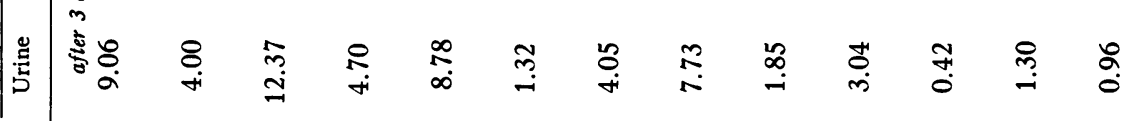

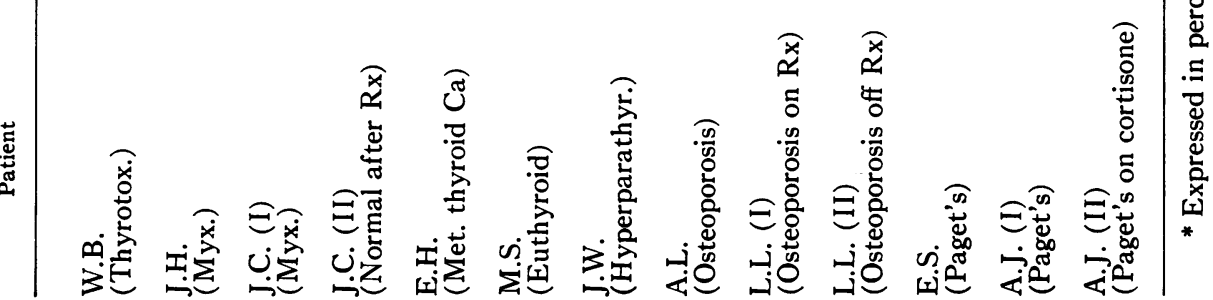




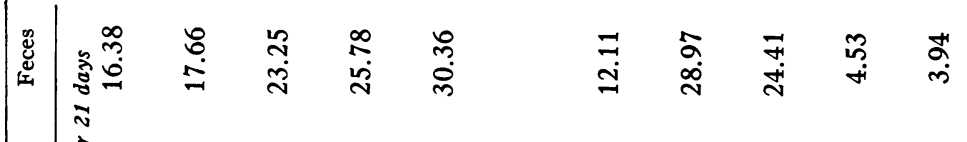

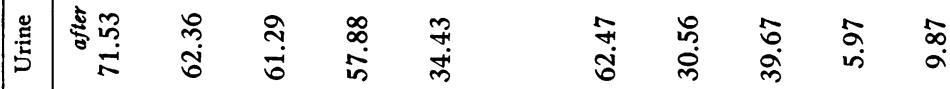

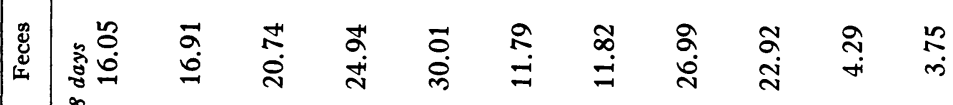

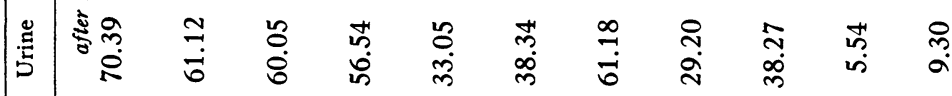

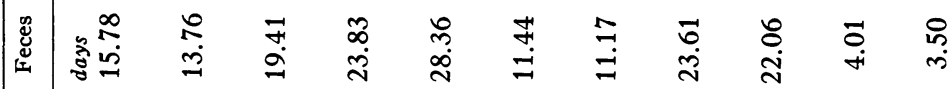

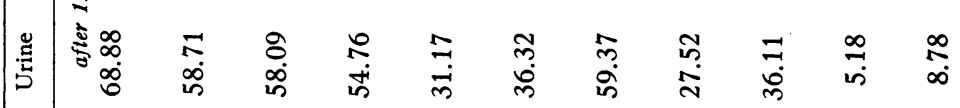

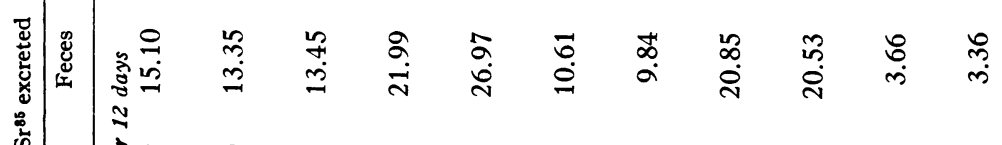

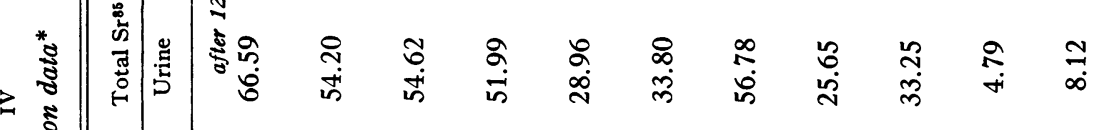

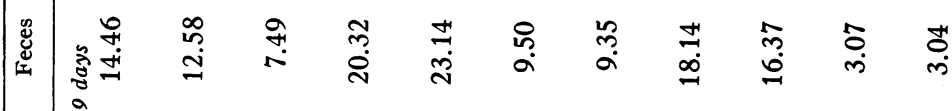

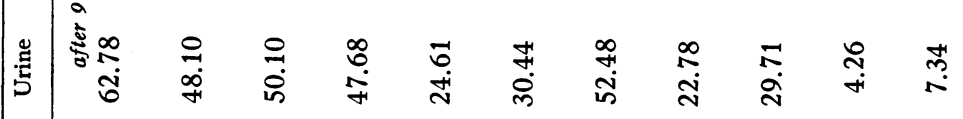

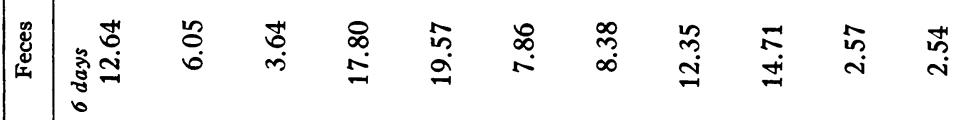

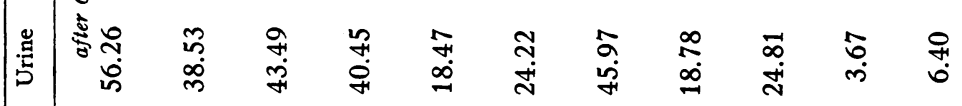

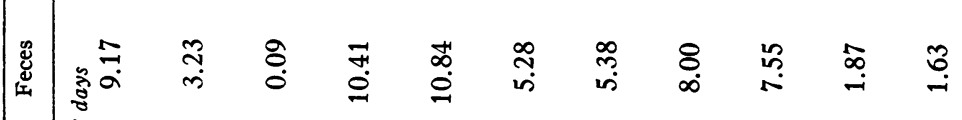

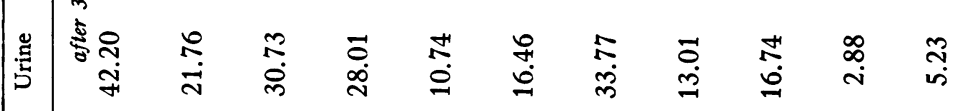

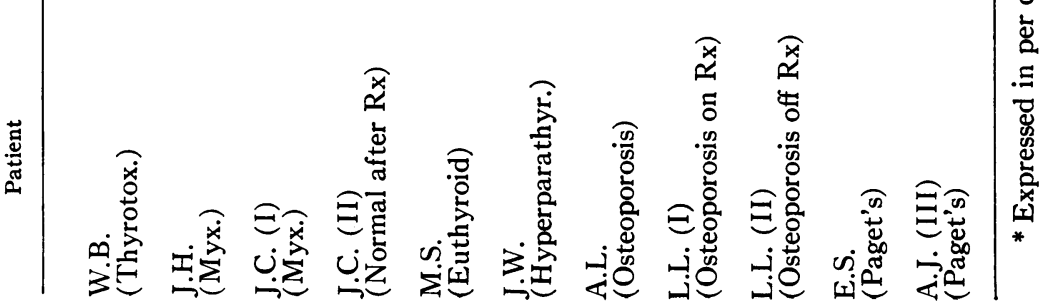


When calculated for specific times the resulting curve represents the ratio between the curve of isotope retention and the specific activity curve. The dimension of the pool is in grams.

The calcium "pool" is a quantitative approximation of the amount of body calcium that has mixed with the administered labeled isotope at a specific time, and provides a value for comparison of patients with different bone diseases. Since the skeleton contains 99 per cent of the total body calcium, calcium "pools"-especially at later times-are related to the mass of bone that has mixed. For each isotope, "pool" sizes based on urine and serum specific activities were determined at 3-day intervals.

\section{RESULTS}

Isotopic excretion data. In all disease states and at all times, the patient retained more $\mathrm{Ca}^{45}$ than $\mathrm{Sr}^{85}$; the ratio of retention of $\mathrm{Ca}^{45}$ to that of $\mathrm{Sr}^{85}$ varied from 1.1 to 5.7. Figure 2 and Tables III and IV show that 1.9 to 8.1 times more $\mathrm{Sr}^{85}$ than $\mathrm{Ca}^{45}$ appeared in the urine.

While renal excretion was the major route of
$\mathrm{Sr}^{85}$ elimination, fecal loss of $\mathrm{Sr}^{85}$ was substantial. As much as 30 per cent of the administered dose was lost by this route within the first 21 days. On the other hand, fecal losses of each isotope were equal.

There was no correlation between the total labeled calcium or strontium and the total stable calcium excreted.

Specific activities. Urine and serum specific activity curves of characteristic form are illustrated in Figures 3 through 6 . Initially, $\mathrm{Sr}^{85}$ "specific activity" in the urine was three to eight times larger than that of $\mathrm{Ca}^{45}$. As each study progressed, the difference between the two values decreased so that the respective urine specific activity curves converged and in some cases intersected (Figure 5 ).

The serum specific activities for each labeled isotope were initially the same and fell close together for at least the first 24 hours and in some cases for the next six days (Figure 4). There-

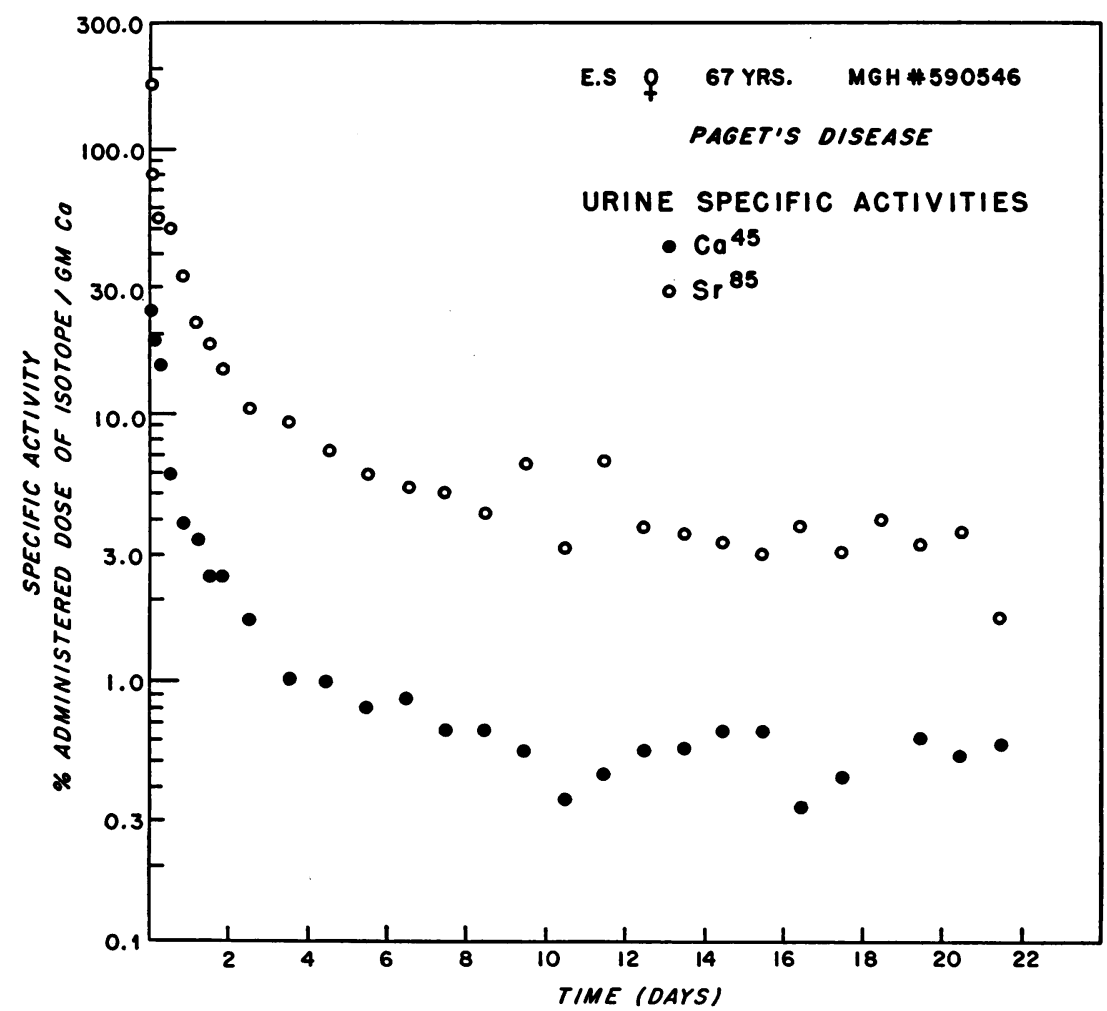

Fig. 3. $\mathrm{CA}^{45}$ AND $\mathrm{SR}^{85}$ URINE SPECIFIC ACTIVITIES PLOTTED SEMILOGARITH MiCALLY against time from data of Subject E.S. With Paget's disease of bone. It is evident that urine values of $\mathrm{Sr}^{85}$ are distinctly higher than are $\mathrm{Ca}^{45}$ values throughout the period of study. 


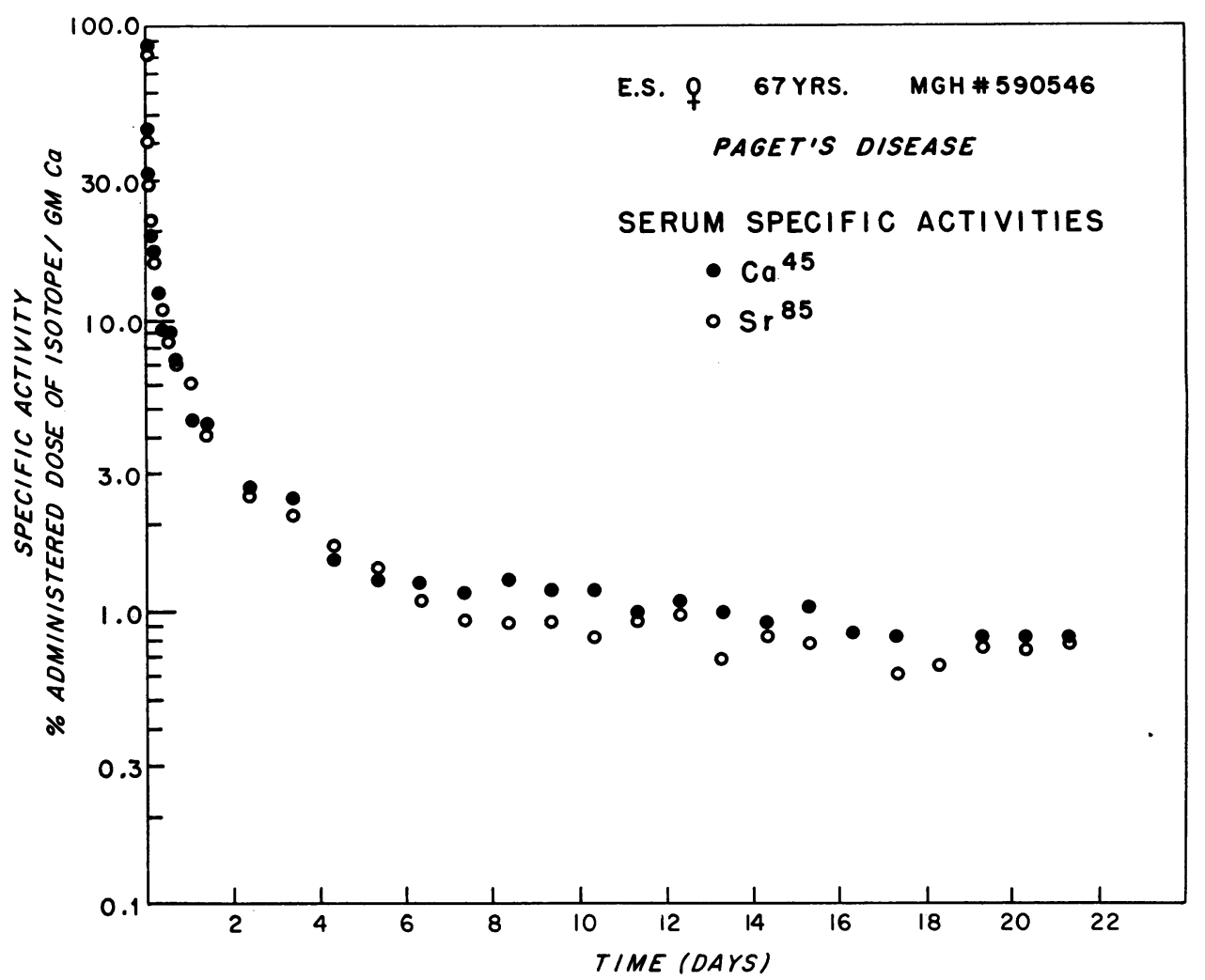

Fig. 4. $\mathrm{CA}^{45}$ AND $\mathrm{SR}^{85}$ SERUM SPECIFIC ACTIVItIES PLOTTED SEMIlogarith MiCALly AGAINST time from data of Subject E.S. With Paget's disease of bone. In contrast to urine curves, the curves here are very approximate, indicating that both isotopes were cleared from the serum at similar rates.

after $\mathrm{Sr}^{85}$ values were increasingly lower so that the two curves diverged.

In all patients, $\mathrm{Ca}^{45}$ specific activities in the serum were consistently greater than those in the urine at corresponding times (Table V). The ratio of serum to urine values differed in the various disease states. For euthyroid subjects, the ratio was of the order of 1.30 ; in thyrotoxicosis, 1.54 ; in myxedema, 1.18 ; and in the two patients with Paget's disease, ratios of 1.77 and 3.86 were found. In the patient with idiopathic progressive osteoporosis, the ratio was 1.39; and in Patient L.L., who had osteoporosis of the "postmenopausal" type, a ratio of 1.80 (while receiving estrogen) fell to 1.49 after therapy was omitted.

Rate constants, coefficients and compartment sizes. There was no difference between the rate constants for $\mathrm{Ca}^{45}$ and $\mathrm{Sr}^{85}$, either in first or second exponential components of the serum or in urine curves (Table VI). In the third compo- nent of the respective curves, $\mathrm{Sr}^{85}$ rate constants were suggestively larger than $\mathrm{Ca}^{45}$ values.

Coefficients and compartment sizes varied significantly in the different disease states. The differences were largest in the third compartment. Third compartment data based on urine measurements showed that $\mathrm{Sr}^{85}$ values paralleled those of $\mathrm{Ca}^{45}$ (Table VII). Compartment sizes based on the serum curves were essentially the same for each isotope in each individual case (Table VIII).

Calcium "pools." Expressing the data in terms of sequential pool sizes indicated the rapidity and extent to which either isotope entered the body calcium spaces. When the $\mathrm{Ca}^{45}$ data from urine measurements were employed, the "pool" sizes at three-day intervals (Figure 7) were in good agreement with those found in similar patients previously reported from this laboratory (1). Table IX demonstrates that the "pool sizes" based on serum specific activities were similar for 
both $\mathrm{Ca}^{45}$ and $\mathrm{Sr}^{85}$ in each patient. At specific times the pool sizes by either isotope varied significantly among the different disease states.

Paget's disease. The largest retention of either isotope was seen in the patients with Paget's disease. Even at the end of 45 days, Patient A.J. (III) had excreted only 18.1 per cent of the administered $\mathrm{Sr}^{85}$. Furthermore, in Paget's disease the body retention curves of both isotopes were quite similar. The ratio of $\mathrm{Ca}^{45}$ to $\mathrm{Sr}^{85}$ retention never exceeded 1.1:1. Specific activities of serum, urine and feces were lowest, and compartment sizes and calcium "pools" were the largest observed among the patients studied.

A three-week $\mathrm{Ca}^{45}$ study was performed before (A.J. I) and ten days after institution of cortisone (A.J. II). While cortisone did not significantly alter the serum chemical determinations as shown in Table II, or detectably alter thyroid function, after eight days on therapy the cardiac index ${ }^{3}$ fell from a control value of 9.9 to 4.6, and daily urinary calcium excretion was reduced 30 per cent. Cortisone caused no dramatic change in $\mathrm{Ca}^{45}$ kinetics. Although the drug seemed to cause a moderate reduction in urine $\mathrm{Ca}^{45}$, compartment sizes and calcium "pools," all of these parameters remained decidedly abnormal.

Thyroid and parathyroid disorders. Skeletal kinetics as measured by either isotope proved sensitive to the level of thyroid function (Tables VII, VIII, IX). Large compartment sizes and calcium "pools" were found in thyrotoxicosis, and low values in myxedema. The expected change in these parameters (based on $\mathrm{Sr}^{85}$ data) was not found when Patient J.C. was restudied after treat-

\footnotetext{
3 The cardiac index is the cardiac output in liters per minute per square meter of body surface by the dye dilution technique. We are indebted to Dr. Lewis Dexter, of the Peter Bent Brigham Hospital, and his laboratory staff for doing these procedures.
}

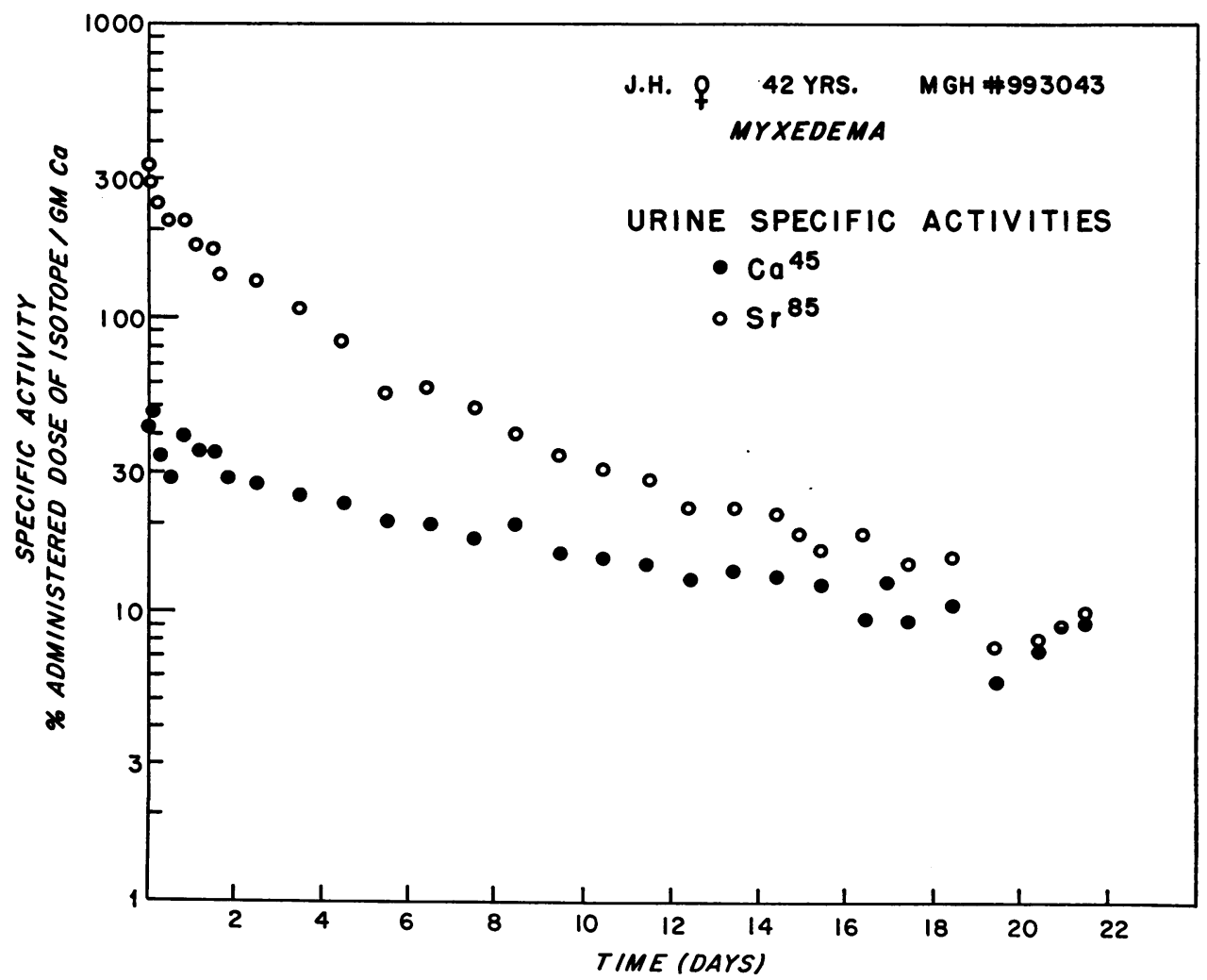

Fig. 5. $\mathrm{CA}^{45}$ AND $\mathrm{SR}^{85}$ URINe SPECIFIC ACtivities Plotted SEMIlogarithmically against TIME FROM DATA OF SUBJECT J.H. With MYXedeMa. Due to differences in rates of excretion of the two isotopes, the curves intersect at the end of the study. 


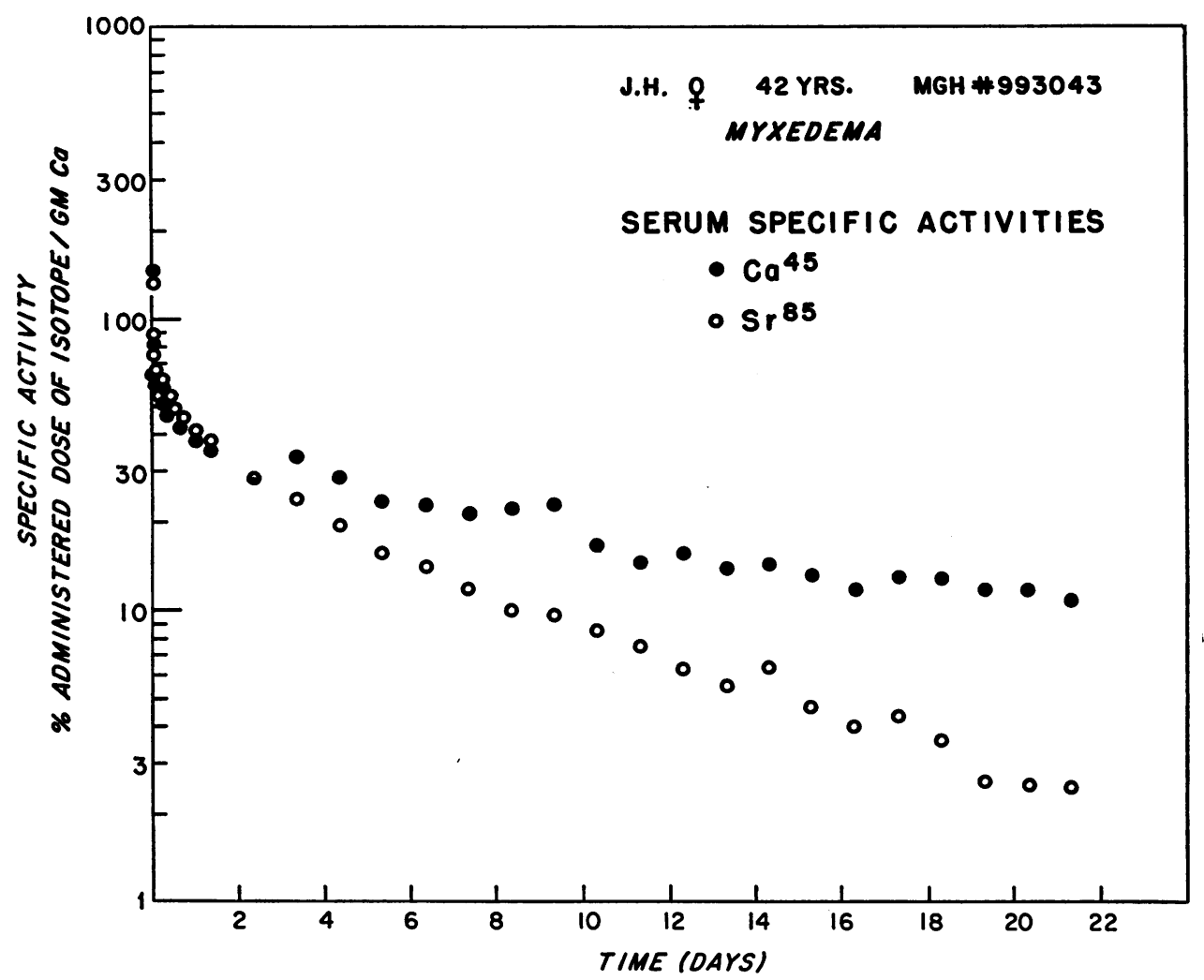

Fig. 6. $\mathrm{CA}^{45}$ AND $\mathrm{SR}^{85}$ SPECIFIC ACTIVITIES PLOTTED SEMILOGARITHMICALLY AGAINST TIME FROM dAta of Subject J.H. With MyXedema. Early divergence of the two curves indicates that $\mathrm{Sr}^{85}$ is more rapidly cleared from the serum. Contrast with Paget's disease, Figure 4.

ment for his myxedema. Simple gross isotopic retention values did not discriminate between thyrotoxicosis and myxedema. Each isotope was retained to about the same degree in both disease states.

Patient E.H., with thyroid cancer metastatic to several bone areas, showed no evidence of increased calcium turnover by any of the criteria employed. Also, the data obtained in J.W., who had hyperparathyroidism but no clinical evidence of bone disease, appeared normal. In both of these cases serum alkaline phosphatase concentrations were repeatedly normal.

Osteoporosis. The two patients with osteoporosis showed no unusual pattern of excretion of stable or labeled calcium or strontium. Although Patient L.L., a postmenopausal female with clinically static disease, had lower compartment sizes and calcium "pools," Patient A.L., with progressive active osteoporosis, displayed values similar to those of the euthyroid controls.
Patient L.L. was restudied four months after cessation of estrogen therapy. Despite a definite increase in the output of stable and labeled calcium in the urine, specific activity curves retained the same appearance, compartment sizes were unchanged, and the calcium "pool" curves were practically superimposable on those obtained when the patient was receiving therapy.

\section{DISCUSSION}

Interest in the physiological similarity of strontium to calcium began in 1870 when Papillon (3) reported that a "certain amount" of this element could be substituted for the calcium normally present in bone. A few years later König (4) found that ingested strontium was deposited in bone. In 1883, Ringer and Sainsbury (5) demonstrated that strontium was similar to calcium ion in its action on the contractility of the ventricle of the frog's heart. Subsequently it has been found that strontium prevents and con- 
trols parathyroid tetany (6), stimulates activity of the uterus (7) and is effective in blood clotting (8).

Although the human skeleton contains only traces of strontium $(9,10)$, under suitable circumstances it can store appreciable amounts of this element $(11,12)$. As with calcium, virtually all deposition takes place in bone. Furthermore, the movement of strontium in and out of the skeleton parallels that of calcium under the influence of such agents as parathyroid hormone and vitamin D (13-15). Strontium, a divalent ion of similar ionic radius $(1.13 \AA$ compared with $0.99 \AA$ for calcium ion), exchanges heterionically with calcium on an equimolar basis and is incorporated into the crystals of bone (16). As with calcium, strontium deposition is not uniform but varies in different bones and in different parts of the same bone, the greatest concentration being invariably in areas of active growth and recent mineralization (17-19).

Despite these similarities strontium cannot serve the purpose of lime salt in bone. Shipley and Park, extending Lehnerdt's earlier work (20), showed that when strontium completely replaces calcium in an otherwise adequate diet, "strontium" rickets develops (21). Von Hodel's finding that strontium is preferentially excreted by the kidney has been confirmed many times (22). Gastrointestinal absorption seems to favor calcium over strontium by a factor of about 2 (23). Nevertheless, by eliminating the kidneys and minimizing the role of the gastrointestinal system

TABLE V

$C a^{45}$ serum to urine specific activity ratios*

\begin{tabular}{lccc}
\hline \multicolumn{1}{c}{ Patient } & $\begin{array}{c}\text { Ca45 specific activity, } \\
\text { serum }\end{array}$ & $\begin{array}{c}\text { Cats specific activity } \\
\text { urine }\end{array}$ & $\begin{array}{c}\text { Ratio } \\
\text { Serum/urine }\end{array}$ \\
\hline $\begin{array}{l}\text { W.B. } \\
\text { (Thyrotox.) }\end{array}$ & $1.99 \pm 0.14$ & $1.29 \pm 0.03$ & $1.54 \pm 0.11$ \\
$\begin{array}{l}\text { J.H. } \\
\text { (Myx.) }\end{array}$ & $15.53 \pm 0.28$ & $13.18 \pm 0.22$ & $1.18 \pm 0.03$ \\
$\begin{array}{l}\text { J.C. (I) } \\
\text { (Myx.) }\end{array}$ & $8.09 \pm 0.32$ & $6.24 \pm 0.27$ & $1.30 \pm 0.07$ \\
$\begin{array}{l}\text { J.C. (II) } \\
\text { (Normal after Rx) }\end{array}$ & $8.89 \pm 0.33$ & $3.93 \pm 0.09$ & $2.26 \pm 0.10$ \\
$\begin{array}{l}\text { E.H. } \\
\text { (Met. thyroid Ca) }\end{array}$ & $7.35 \pm 0.23$ & $5.77 \pm 0.14$ & $1.27 \pm 0.05$ \\
$\begin{array}{l}\text { M.S. } \\
\text { (Euthyroid) }\end{array}$ & $9.44 \pm 0.16$ & $7.76 \pm 0.54$ & $1.22 \pm 0.09$ \\
$\begin{array}{l}\text { J.W. } \\
\text { (Hyperparathyr.) }\end{array}$ & $4.72 \pm 0.21$ & $3.16 \pm 0.05$ & $1.49 \pm 0.07$ \\
$\begin{array}{l}\text { A.L. } \\
\text { (Osteoporosis) }\end{array}$ & $4.58 \pm 0.30$ & $3.29 \pm 0.06$ & $1.39 \pm 0.09$ \\
$\begin{array}{l}\text { L.L. (I) } \\
\text { (Osteoporosis on Rx) }\end{array}$ & $11.30 \pm 0.29$ & $6.29 \pm 0.20$ & $1.80 \pm 0.07$ \\
$\begin{array}{l}\text { L.L. (II) } \\
\text { (Osteoporosis off Rx) }\end{array}$ & $10.21 \pm 0.30$ & $6.83 \pm 0.21$ & $1.49 \pm 0.06$ \\
$\begin{array}{l}\text { E.S. } \\
\text { (Paget's) }\end{array}$ & $0.993 \pm 0.01$ & $0.562 \pm 0.03$ & $1.77 \pm 0.10$ \\
$\begin{array}{l}\text { A.J. (I) } \\
\text { (Paget's) }\end{array}$ & $1.66 \pm 0.16$ & $0.430 \pm 0.01$ & $3.86 \pm 0.38$ \\
$\begin{array}{l}\text { A.J. (II) } \\
\text { (Paget's on cortisone) }\end{array}$ & $2.12 \pm 0.39$ & $0.624 \pm 0.05$ & $3.40 \pm 0.70$ \\
\hline
\end{tabular}

* The $\mathrm{Ca}^{45}$ serum and urine specific activity values are determined at Day 13 which represents the average time $(t)$ of the period corresponding to the third phase of the individual curves (Days 5 to 21). The differences between serum and urine values in each case are significant $(p<0.01)$. 


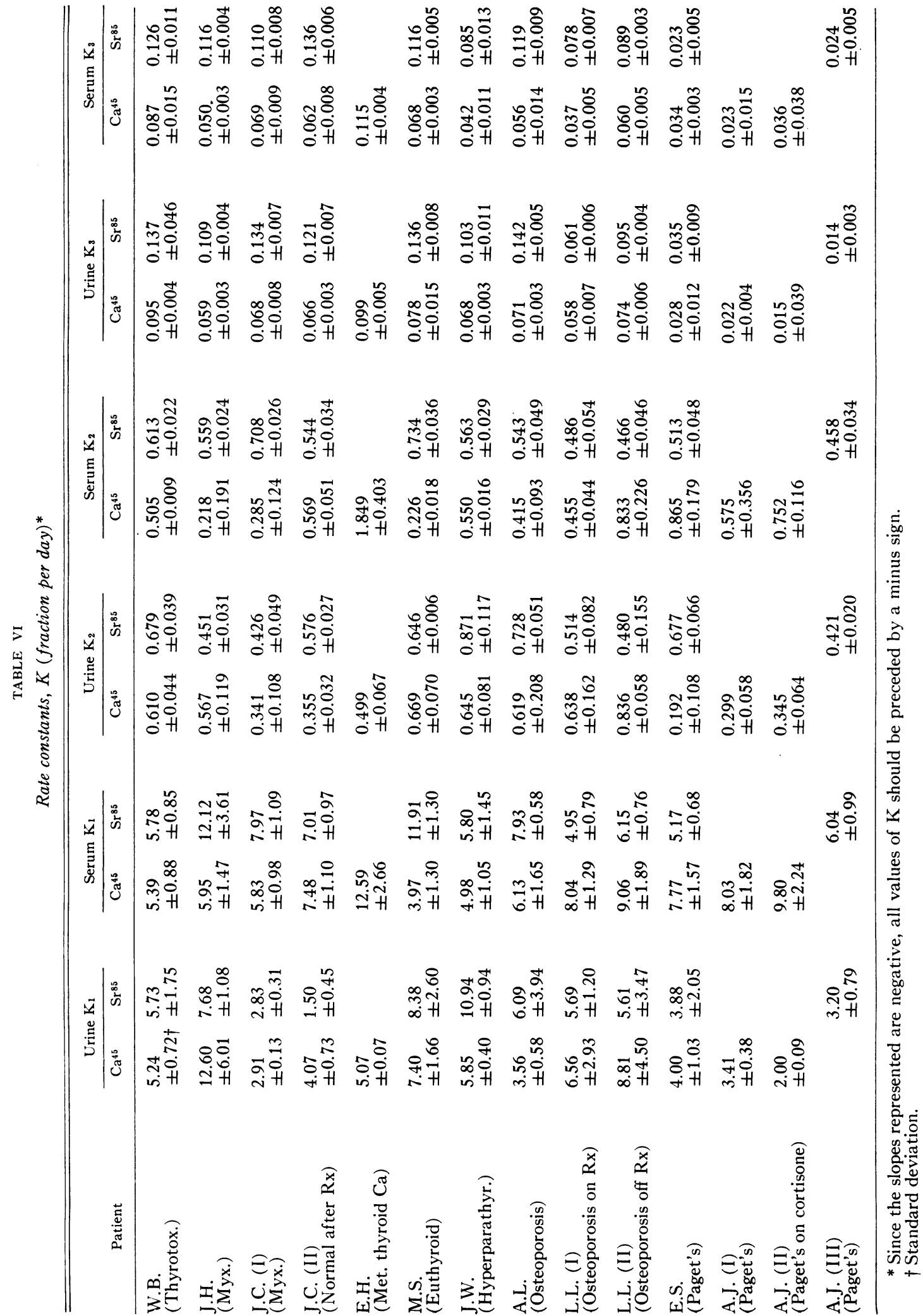


in experimental animals, MacDonald, Noyes and Larick were able to show that the skeleton per se was not able to discriminate between trace amounts of calcium and strontium (24).

Present considerations. The present studies were designed with the above considerations in mind. The use of $\mathrm{Sr}^{85}$ and $\mathrm{Ca}^{45}$ of high specific activity eliminated distortions due to unphysiological amounts of test material. Selecting the intravenous route for administration minimized the role of the gastrointestinal system, and administration of both isotopes simultaneously permitted comparative study of each in the same patient at the same time.

The findings reported here are not in full agreement with those of McCance and Widdow- son (25), nor with those of Harrison, Raymond and Tretheway (26). Those studies, based on administration of larger amounts of stable strontium, showed fecal excretion of strontium to be minimal. Although fecal excretion of $\mathrm{Ca}^{45}$ and $\mathrm{Sr}^{85}$ did not vary greatly among the patients studied here, except in those with Paget's disease, the amounts of each labeled isotope eliminated by this route were sizable and could neither be ignored nor considered constant. The renal excretion data are in good agreement with the many animal and human studies already reported $(23,24,27-29)$ and indicate that the ratio of renal clearance of strontium to calcium is about 5 .

Whole body retention values of either $\mathrm{Sr}^{85}$ or $\mathrm{Ca}^{45}$ did not provide a suitable index of skeletal

TABLE VII

Compartment size (grams) based on urine coefficients

\begin{tabular}{|c|c|c|c|c|c|c|}
\hline \multirow[b]{2}{*}{ Patient } & \multicolumn{2}{|c|}{ I } & \multicolumn{2}{|c|}{ II } & \multicolumn{2}{|c|}{ III } \\
\hline & $\mathrm{Ca}$ & $\mathrm{Sr}$ & $\mathrm{Ca}$ & $\mathrm{Sr}$ & $\mathrm{Ca}$ & $\mathrm{Sr}$ \\
\hline $\begin{array}{l}\text { W.B. } \\
\text { (Thyrotox.) }\end{array}$ & 2.74 & 0.571 & 5.45 & 1.14 & 22.42 & 5.07 \\
\hline $\begin{array}{l}\text { J.H. } \\
\text { (Myx.) }\end{array}$ & 1.32 & 0.281 & 2.42 & 0.383 & 3.53 & 0.980 \\
\hline $\begin{array}{l}\text { J.C. (I) } \\
\text { (Myx.) }\end{array}$ & 1.49 & 0.515 & 3.09 & 1.11 & 6.64 & 2.39 \\
\hline $\begin{array}{l}\text { J.C. (II) } \\
\text { (Normal after Rx) }\end{array}$ & 2.64 & 0.339 & 4.60 & 0.536 & 10.82 & 1.98 \\
\hline $\begin{array}{l}\text { E.H. } \\
\text { (Met. thyroid Ca) }\end{array}$ & 1.49 & & 3.12 & & 4.78 & \\
\hline $\begin{array}{l}\text { M.S. } \\
\text { (Euthyroid) }\end{array}$ & 1.63 & 0.249 & 4.32 & 0.398 & 4.66 & 0.556 \\
\hline $\begin{array}{l}\text { J.W. } \\
\text { (Hyperparathyr.) }\end{array}$ & 2.24 & 0.683 & 5.19 & 1.03 & 13.07 & 3.94 \\
\hline $\begin{array}{l}\text { A.L. } \\
\text { (Osteoporosis) }\end{array}$ & 3.13 & 0.638 & 6.56 & 0.960 & 12.11 & 3.38 \\
\hline $\begin{array}{l}\text { L.L. (I) } \\
\text { (Osteoporosis on } \mathrm{Rx} \text { ) }\end{array}$ & 1.98 & 0.227 & 3.66 & 0.459 & 7.49 & 1.54 \\
\hline $\begin{array}{l}\text { L.L. (II) } \\
\text { (Osteoporosis off Rx) }\end{array}$ & 1.59 & 0.262 & 2.59 & 0.694 & 5.59 & 1.37 \\
\hline $\begin{array}{l}\text { E.S. } \\
\text { (Paget's) }\end{array}$ & 4.55 & 0.756 & 29.06 & 2.37 & 123.30 & 15.80 \\
\hline $\begin{array}{l}\text { A.J. (I) } \\
\text { (Paget's) }\end{array}$ & 7.13 & & 44.76 & & 174.2 & \\
\hline $\begin{array}{l}\text { A.J. (II) } \\
\text { (Paget's on cortisone) }\end{array}$ & 8.65 & & 30.56 & & 131.23 & \\
\hline $\begin{array}{l}\text { A.J. (III) } \\
\text { (Paget's) }\end{array}$ & & 1.31 & & 6.41 & & 44.25 \\
\hline
\end{tabular}


TABLE VIII

Compartment size (grams) based on serum coefficients

\begin{tabular}{|c|c|c|c|c|c|c|}
\hline \multirow[b]{2}{*}{ Patient } & \multicolumn{2}{|c|}{ I } & \multicolumn{2}{|c|}{ II } & \multicolumn{2}{|c|}{ III } \\
\hline & $\mathrm{Ca}$ & $\mathrm{Sr}$ & $\mathrm{Ca}$ & $\mathrm{Sr}$ & $\mathrm{Ca}$ & $\mathrm{Sr}$ \\
\hline $\begin{array}{l}\text { W.B. } \\
\text { (Thyrotox.) }\end{array}$ & 1.51 & 1.39 & 4.48 & 3.36 & 16.18 & 17.57 \\
\hline $\begin{array}{l}\text { J.H. } \\
\text { (Myx.) }\end{array}$ & 1.11 & 1.00 & 2.47 & 1.75 & 3.36 & 3.55 \\
\hline $\begin{array}{l}\text { J.C. (I) } \\
\text { (Myx.) }\end{array}$ & 1.13 & 1.17 & 2.95 & 2.42 & 5.05 & 7.19 \\
\hline $\begin{array}{l}\text { J.C. }(\text { II) } \\
\text { (Normal after Rx) }\end{array}$ & 1.31 & 1.15 & 2.73 & 2.58 & 5.05 & 6.25 \\
\hline $\begin{array}{l}\text { E.H. } \\
\text { (Met. thyroid Ca) }\end{array}$ & 0.969 & & 1.78 & & 3.05 & \\
\hline $\begin{array}{l}\text { M.S. } \\
\text { (Euthyroid) }\end{array}$ & 1.55 & 1.116 & 2.89 & 2.32 & 4.41 & 4.83 \\
\hline $\begin{array}{l}\text { J.W. } \\
\text { (Hyperparathyr.) }\end{array}$ & 2.59 & 2.57 & 6.55 & 5.23 & 12.27 & 13.00 \\
\hline $\begin{array}{l}\text { A.L. } \\
\text { (Osteoporosis) }\end{array}$ & 2.45 & 1.56 & 5.20 & 4.24 & 10.57 & 14.84 \\
\hline $\begin{array}{l}\text { L.L. (I) } \\
\text { (Osteoporosis on Rx) }\end{array}$ & 0.928 & 1.11 & 2.38 & 2.76 & 5.49 & 5.96 \\
\hline $\begin{array}{l}\text { L.L. (II) } \\
\text { (Osteoporosis off Rx) }\end{array}$ & 0.712 & 0.945 & 2.27 & 2.91 & 4.50 & 6.94 \\
\hline $\begin{array}{l}\text { E.S. } \\
\text { (Paget's) }\end{array}$ & 2.46 & 2.64 & 9.43 & 13.50 & 64.52 & 91.74 \\
\hline $\begin{array}{l}\text { A.J. (I) } \\
\text { (Paget's) }\end{array}$ & 2.82 & & 22.17 & & 44.44 & \\
\hline $\begin{array}{l}\text { A.J. (II) } \\
\text { (Paget's on cortisone) }\end{array}$ & 2.35 & & 14.62 & & 26.32 & \\
\hline $\begin{array}{l}\text { A.J. (III) } \\
\text { (Paget's) }\end{array}$ & & 3.43 & & 22.57 & & 156.01 \\
\hline
\end{tabular}

function, except in Paget's disease. Retention of these two elements is a resultant of three main processes, viz., skeletal uptake, renal excretion and fecal elimination. In Paget's disease, skeletal uptake is exaggerated to the extent that relatively little of either labeled isotope is available for excretion. The kidneys compete more successfully with the skeleton in thyrotoxic patients than in the normal subjects, in clearing calcium and strontium from the serum. The result is a normal or low body retention. In myxedema, reduced skeletal uptake permits the excretory mechanisms more opportunity to clear the serum and, therefore, as in thyrotoxicosis but for different reasons, the body retention values are similarly low.
Spencer, Laszlo and Brothers found the plasma level of $\mathrm{Ca}^{45}$ higher than that of $\mathrm{Sr}^{85}$ throughout a 12-day study in a patient to whom both isotopes were administered orally. Blood data for the first 24 hours were not presented in their report (23). Norris and Kisielski, on the other hand, found that the blood concentrations of $\mathrm{Sr}^{89}$ remained above those of $\mathrm{Ca}^{45}$ in mice receiving tracers intravenously (30).

In all of the present studies the concentrations of $\mathrm{Sr}^{85}$ and $\mathrm{Ca}^{45}$ in the serum were equal for at least the first 24 hours. In Paget's disease, where both isotopes were cleared from the serum primarily by exaggerated skeletal uptake, the serum values of each isotope remained equal for at least six days and differed only slightly thereafter 


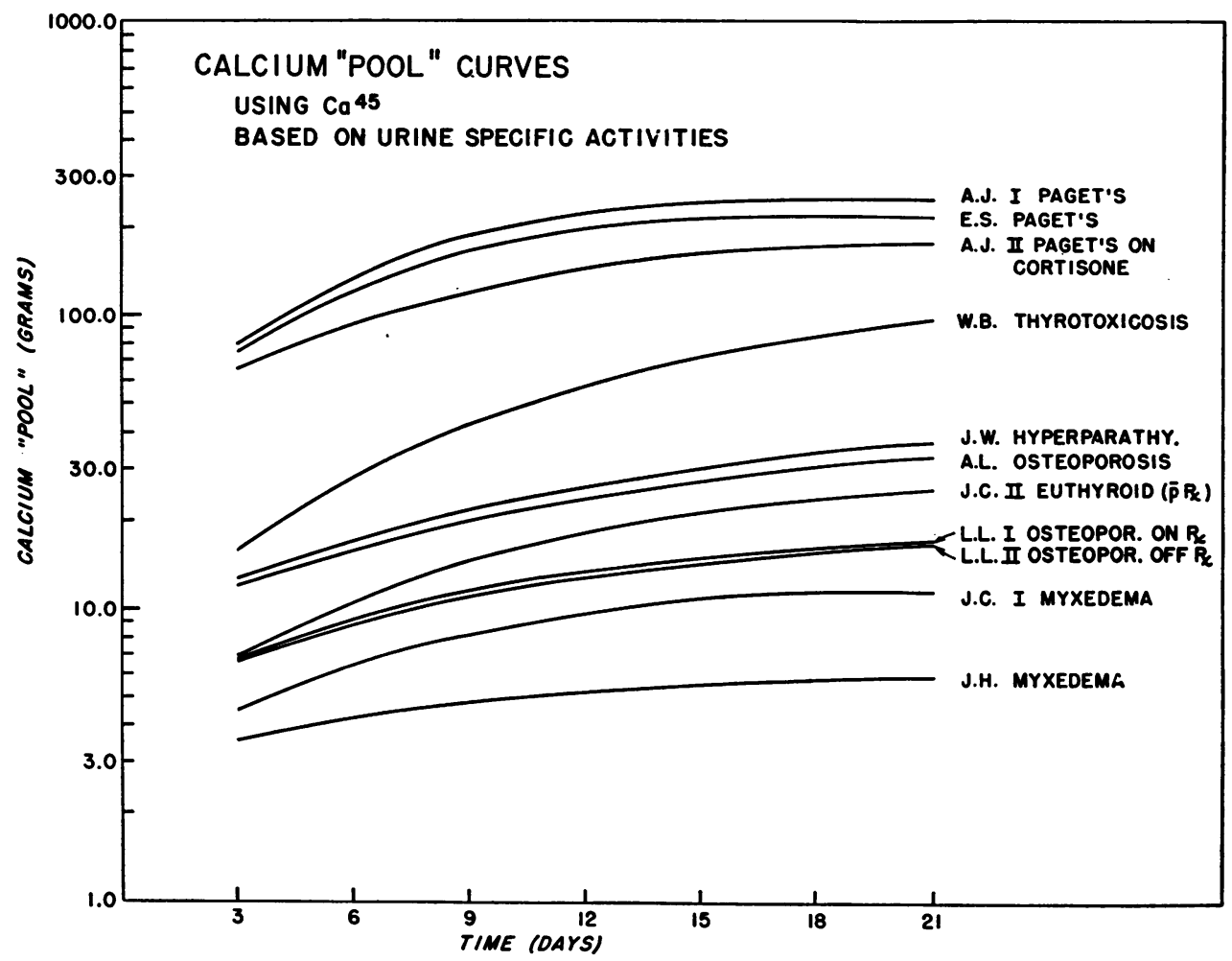

Fig. 7. Calcium "PoOL" In GRAms. $\frac{\text { Per cent } \mathrm{Ca}^{45} \text { remaining in body at time } \mathrm{t}}{\mathrm{Ca}^{45} \text { urine specific activity at time } \mathrm{t}}$, plotted semilogarithmically against time. To preserve clarity the individual values are not plotted.

(Figure 4). The earliest diversion of $\mathrm{Sr}^{85}$ and skeleton itself does not discriminate between the $\mathrm{Ca}^{45}$ serum values was seen in myxedema (Figure 6) where skeletal activity is much reduced. These findings provide indirect evidence that the two isotopes.

Model compartment systems. Various investigators have proposed model compartment systems

TABLE IX

"Pool sizes" (grams) based on serum specific activities

\begin{tabular}{|c|c|c|c|c|c|c|c|c|c|c|c|c|}
\hline \multirow{2}{*}{$\begin{array}{l}\text { Time } \\
\text { in days }\end{array}$} & \multicolumn{2}{|c|}{ W.B. (Thyrotox.) } & \multicolumn{2}{|c|}{ J.H. (Myx.) } & \multicolumn{2}{|c|}{ J.C. (I) (Myx.) } & \multicolumn{2}{|c|}{$\underset{\text { (Normal after Rx) }}{\text { J.C. (II) }}$} & \multicolumn{2}{|c|}{ M.S. (Euthyroid) } & \multicolumn{2}{|c|}{$\begin{array}{l}\text { J.W. } \\
\text { (Hyperparathyroid) }\end{array}$} \\
\hline & Calcium & Strontium & Calcium & Strontium & Calcium & Strontium & Calcium & Strontium & Calcium & Strontium & Calcium & Strontium \\
\hline \multirow[t]{2}{*}{$\begin{array}{r}3 \\
6 \\
9 \\
12 \\
15 \\
18 \\
21\end{array}$} & $\begin{array}{r}9.69 \\
17.55 \\
25.22 \\
33.22 \\
40.81 \\
48.34 \\
56.83\end{array}$ & $\begin{array}{r}6.66 \\
10.03 \\
12.30 \\
14.65 \\
17.84 \\
22.98 \\
29.49\end{array}$ & $\begin{array}{l}3.15 \\
3.81 \\
3.96 \\
4.30 \\
4.75 \\
5.09 \\
5.66\end{array}$ & $\begin{array}{l}3.03 \\
3.79 \\
3.97 \\
4.66 \\
5.61 \\
6.31 \\
8.15\end{array}$ & $\begin{array}{r}4.21 \\
5.40 \\
7.10 \\
7.37 \\
7.98 \\
9.36 \\
10.34\end{array}$ & $\begin{array}{r}5.16 \\
6.78 \\
8.08 \\
8.49 \\
8.50 \\
10.01 \\
11.28\end{array}$ & $\begin{array}{r}4.54 \\
5.88 \\
6.60 \\
7.65 \\
8.63 \\
10.00 \\
11.76\end{array}$ & $\begin{array}{r}4.28 \\
5.35 \\
6.81 \\
8.39 \\
10.29 \\
13.53 \\
17.20\end{array}$ & $\begin{array}{r}3.99 \\
5.25 \\
6.59 \\
7.98 \\
9.29 \\
10.92 \\
13.24\end{array}$ & $\begin{array}{r}4.48 \\
5.63 \\
7.10 \\
8.47 \\
11.09 \\
14.31 \\
19.34\end{array}$ & $\begin{array}{l}10.80 \\
13.49 \\
15.26 \\
16.90 \\
18.73 \\
20.98\end{array}$ & $\begin{array}{r}9.66 \\
13.77 \\
16.82 \\
20.21 \\
24.52 \\
30.22\end{array}$ \\
\hline & \multicolumn{2}{|c|}{ A. L. (Osteoporosis) } & \multicolumn{2}{|c|}{$\begin{array}{l}\text { L. L. (I) } \\
\text { (Osteoporosis on Rx) }\end{array}$} & \multicolumn{2}{|c|}{$\begin{array}{l}\text { L. L. (II) } \\
\text { (Osteoporosis off Rx) }\end{array}$} & \multicolumn{2}{|c|}{ E. S. (Paget's) } & \multicolumn{2}{|c|}{ A. J. (I) A. J. (Paget's) $^{(I I I) *}$} & \multicolumn{2}{|c|}{$\begin{array}{c}\text { A. J. (II) } \\
\text { (Paget's on cortisone) }\end{array}$} \\
\hline $\begin{array}{r}3 \\
6 \\
9 \\
12 \\
15 \\
18 \\
21\end{array}$ & $\begin{array}{r}8.82 \\
10.70 \\
13.01 \\
15.06 \\
16.91 \\
19.14 \\
22.21\end{array}$ & $\begin{array}{r}7.65 \\
11.41 \\
15.77 \\
20.60 \\
26.06 \\
33.75 \\
46.21\end{array}$ & $\begin{array}{l}4.24 \\
5.66 \\
6.59 \\
7.25 \\
7.84 \\
8.59 \\
9.34\end{array}$ & $\begin{array}{r}4.56 \\
6.09 \\
7.11 \\
8.19 \\
9.43 \\
10.68 \\
12.56\end{array}$ & $\begin{array}{r}4.42 \\
5.62 \\
6.75 \\
7.79 \\
9.00 \\
10.52 \\
12.32\end{array}$ & $\begin{array}{r}4.88 \\
6.23 \\
8.10 \\
9.24 \\
10.94 \\
13.24 \\
15.96\end{array}$ & $\begin{array}{r}44.82 \\
73.77 \\
85.77 \\
94.73 \\
104.63 \\
115.61 \\
127.43\end{array}$ & $\begin{array}{r}43.30 \\
76.85 \\
101.82 \\
110.30 \\
117.94 \\
125.25 \\
133.58\end{array}$ & $\begin{array}{l}40.41 \\
49.05 \\
53.12 \\
56.73 \\
60.88 \\
64.84 \\
69.27\end{array}$ & $\begin{array}{r}64.23 \\
116.74 \\
169.10 \\
184.40 \\
195.80 \\
208.40 \\
227.40\end{array}$ & $\begin{array}{l}25.06 \\
30.99 \\
35.75 \\
38.90 \\
43.12 \\
47.75\end{array}$ & \\
\hline
\end{tabular}

* $\mathrm{Sr}^{85}$ study done 8 months after $\mathrm{Ca}^{45}$ study. 
in attempts to quantitate calcium kinetics in the living organism. The application of these systems to data from experiments of diversified design accounts for the lack of uniformity in the published reports $(1,26,28,31,32)$. All of the curve analyses reported here were based on an arbitrary three-compartment system. No assumption was made that the values recorded were physiologically real. Rather, these analyses provided information for two considerations; first, they allowed for quantitative comparison of $\mathrm{Sr}^{85}$ and $\mathrm{Ca}^{45}$ kinetics in the same patient and secondly, they indicated that both labeled isotopes were similarly affected by specific bone disorders.

Cortisone and Paget's disease. The findings in Paget's disease corroborate those of Albright and Henneman (33) in that cortisone suppressed the activity of the disease. The effect, while definite, was far from complete in restoring calcium exchange to normal.

Osteoporosis. Two patients with different types of osteoporosis were available for study. A.L., a young male, had active progressive idiopathic osteoporosis, and L.L. had chronic disease of the postmenopausal type. In neither was the body retention of either labeled isotope particularly low. This is in accord with the findings by Heaney and Whedon (32) and of Nordin (34) that calcium "accretion" rates are normal in osteoporosis. Although Patient A.L. was in definite negative calcium and phosphorus balance (nitrogen balance being maintained), compartment sizes and "calcium pools" were normal.

The value of estrogen therapy in "postmenopausal" osteoporosis is difficult to assess. Animal experimentation has not been helpful, because the effect of this steroid varies in different species (35-37). Radiography is technically inadequate to evaluate changes in bone density. Human balance data are scarce and are primarily those of Albright, Bloomberg and Smith (38) and Reifenstein and Albright (39).

Patient L.L. was first studied at a time when she had been receiving $1.25 \mathrm{mg}$ of estrone sulfate $^{4}$ daily for a prolonged period. The control study (L.L. II) was performed after estrogen therapy had been omitted for four months, a suffi-

\footnotetext{
${ }^{4}$ Conjugated equine estrogens (Premarin).
}

cient period of time to insure waning of any estrogenic effect (33). The difference between the means of the calcium balance during the control and the treatment periods was significant $(p<0.05)$. The balance data for calcium and phosphorus are in good agreement with those of Reifenstein and Albright and demonstrated diminished calciuria and phosphaturia during estrogen therapy. However, the fact that $\mathrm{Ca}^{45}$ and $\mathrm{Sr}^{85}$ data showed no differences in skeletal kinetics between the control and estrogen therapy studies suggests that the effects of estrogen are extraosseous.

$C a^{45}$ serum and urine specific activities. Serum $\mathrm{Ca}^{45}$ specific activities consistently higher than corresponding urine values were observed in all cases (Table V). This finding was unexpected and is not in accord with those of others. Most investigators have reported that $\mathrm{Ca}^{45}$ specific activities in urine and serum are similar $(32,40)$. In most of these studies both serum and urine determinations are reported only for the first several days, when both values are changing rapidly. Since serum sampling is essentially instantaneous, urine specific activities determined on collections made over fixed periods of time, and plotted at the midpoint of the period, are erroneously elevated. This is especially true when the urine values are changing rapidly. Bronner, Benda, Harris and Kreplick, in a report of a case of gargoylism noted that "the corresponding values for urine tend, perhaps, to be lower than those for the serum" (41). A review of Baker's Ca ${ }^{45}$ studies in patients with neoplastic disease disclosed that patients with hypercalcemia associated with metastatic calcification, with multiple myeloma, or with carcinoma metastatic to soft tissues and bone from breast and kidney, had identical $\mathrm{Ca}^{45}$ specific activity curves in serum and urine. ${ }^{5}$ Patients with metastatic breast carcinoma, but with normocalcemia, had serum to urine specific activity ratios of over 2 . The most striking dissociation of serum and urine values occurred in a patient with carcinoma of the prostate, widespread bone metastases, and low to normal serum calcium concentrations. $\mathrm{Ca}^{45}$ specific activities in

5 We are indebted to Dr. William Baker for permitting us to examine his unpublished data. 
the serum were consistently five times higher than those in the urine during a nine-day study. In our own studies the ratios varied in different disease states and were highest in Paget's disease and thyrotoxicosis, "normal" in untreated osteoporosis and lowest (1.18) in myxedema. The patient with osteoporosis who received estrogen therapy was found to have a serum to urine $\mathrm{Ca}^{45}$ specific activity ratio of 1.80 , compared with a control value of 1.49 .

Nevertheless, the possibility remains that the observed discrepancy between $\mathrm{Ca}^{45}$ specific activities of blood and urine represents a systematic but undisclosed analytical error. In serum analysis, a positive error in $\mathrm{Ca}^{45}$ counts or a negative error in $\mathrm{Ca}^{40}$ measurement, or both, would result in a higher serum specific activity. Similarly, lowering of urine specific activities would result from a systematic negative error in $\mathrm{Ca}^{45}$ measurements or a positive error in $\mathrm{Ca}^{40}$ determinations, or both. A search for such a source of error has not been 'fruitful. Recovery measurements for $\mathrm{Ca}^{40}$ in serum and urine gave excellent validation of the methods used. The fact that the highest ratios of serum to urine specific activity appeared at lowest values for urine specific activity suggests a systematic error in radioactive isotopic determinations when these are present in low concentration, but recovery experiments with isotopic mixtures failed to disclose such an error. The discrepancy would not appear to be attributable to renal delay, because it was present long after administration of the labeled $\mathrm{Ca}^{45}$, when serum concentrations were changing very slowly from day to day. An alternative but seemingly less probable source of the discrepancy is that $\mathrm{Ca}^{40}$ and $\mathrm{Ca}^{45}$ are bound with different affinities to plasma protein, or are differentially excreted by the kidney, or are differentiated in some other way to account for the departure of the specific activity ratio from unity.

\section{SUMMARY AND CONCLUSIONS}

1. The distribution and excretion of $\mathrm{Sr}^{85}$ and $\mathrm{Ca}^{45}$ administered simultaneously and intravenously were studied in patients with thyroid and parathyroid disorders, osteoporosis, and Paget's disease. In all cases and at all times the body retention of $\mathrm{Ca}^{45}$. was more than $\mathrm{Sr}^{85}$ retention by a factor of 1.1 to 5.7 .

2. Differential renal clearance of the two isotopes accounted for 1.9 to 8.1 times more $\mathrm{Sr}^{85}$ than $\mathrm{Ca}^{45}$ in the urine.

3. The amounts of each isotope in the feces were sizable, generally equal, and varied little in the different diseases studied, except in Paget's disease.

4. Calcium "pools" and compartment sizes as determined by either isotope proved to be sensitive indices of skeletal function. The largest values were found in Paget's disease and thyrotoxicosis and the lowest in myxedema.

5. One patient with thyroid cancer metastatic to bone showed no evidence of increased calcium turnover by any of the criteria employed.

6. A patient with hyperparathyroidism but no clinical evidence of bone disease showed no evidence of abnormal calcium or strontium dynamics.

7. In one patient with Paget's disease cortisone failed to suppress completely the activity of the disease as measured by $\mathrm{Ca}^{45}$ dynamics.

8. There was no unusual pattern of labeled isotope excretion in patients with osfeoporosis. Prolonged estrogen therapy in one patient with osteoporosis of the postmenopausal type effected no change in skeletal kinetics as measured by the metabolism of $\mathrm{Ca}^{45}$ or $\mathrm{Sr}^{85}$ but did effect a change in the serum to urine $\mathrm{Ca}^{45}$ specific activity ratio.

9. The observation that $\mathrm{Ca}^{45}$ specific activities were consistently greater in serum than in urine and the variation of serum to urine ratios in different disease states is discussed as representing either a true phenomenon or a systematic analytical error.

10. $\mathrm{Sr}^{85}$ qualitatively parallels $\mathrm{Ca}^{45}$ as an index of skeletal function in metabolic bone diseases.

\section{ACKNOWLEDGMENTS}

The authors wish to express their gratitude to Drs. Stephen M. Krane and Gordon L. Brownell for their interest and advice, and to Helen J. Corrigan who contributed invaluable technical assistance.

\section{REFERENCES}

1. Krane, S. M., Brownell, G. L., Stanbury, J. B., and Corrigan, $H$. The effect of thyroid diseases on 
calcium metabolism in man. J. clin. Invest. 1956, 35,874 .

2. Snedecor, G. W. Statistical Methods, 4th ed. Ames, Iowa, Iowa State College Press, 1946, p. 103.

3. Papillon, M. F. Recherches expérimentales sur les modifications de la composition immédiate des os. C. R. Acad. Sci. (Paris) 1870, 71, 372.

4. König, J. Substitution des Kalkes in den Knochen. Z. Biol. 1874, 10, 69.

5. Ringer, S., and Sainsbury, H. An investigation regarding the action of strontium and barium salts compared with the action of lime on the ventricle of the frog's heart. Practitioner 1883, 31, 81.

6. Dragstedt, L. R., and Sudan, A. S. Studies on pathogenesis of tetany: The prevention and control of parathyroid tetany by strontium. Amer. J. Physiol. 1926, 77, 307.

7. Harned, B. K., and Cole, V. V. The action of strontium and calcium on the uterus. J. Pharmacol. exp. Ther. 1941, 71, 6.

8. Stefanini, M., and Quick, A. J. Quantitative studies on the comparative activity of calcium and chemically related ions on the coagulation of blood. Amer. J. Physiol. 1948, 152, 389.

9. Hodges, R. M., MacDonald, N. S., Nusbaum, R., Stearns, R., Ezmirlian, F., Spain, P., and McArthur, C. The strontium content of human bones. J. biol. Chem. 1950, 185, 519.

10. Gerlach, W., and Müller, R. Über des Vorkommen von Strontium und Barium in menschlichen Organen und Ausscheidungen. Virchows Arch. path. Anat. 1934, 294, 210.

11. Shorr, E., and Carter, A. C. The usefulness of strontium as an adjuvant to calcium in remineralization of the skeleton in man. Bull. Hosp. Jt Dis. (N. Y.) 1952, 13, 59.

12. Kinney, E. M., and McCollum, E. V. A study of the rate of deposition and paths of absorption of strontium in the rat. J. Pharmacol. exp. Ther. 1923, 21, 165.

13. Greenberg, D. M. Tracer experiments with radioactive calcium and strontium on the mechanism of Vitamin D action in rachitic rats. J. biol. Chem. 1945, 157, 99.

14. Tweedy, W. R. The effect of parathyroid extract upon the distribution, retention, and excretion of labeled strontium. J. biol. Chem. 1945, 161, 105.

15. Weissberger, L. H., and Harris, P. L. A possible Vitamin D assay technique with radioactive strontium. J. biol. Chem. 1942, 144, 287.

16. Neuman, W. F., and Neuman, M. W. Nature of the mineral phase of bone. Chem. Rev. 1953, 53, 1.

17. Jowsey, J., Owen, M., and Vaughan, J. Microradiographs and autoradiographs of cortical bone from monkeys injected with ${ }^{90} \mathrm{Sr}$. Brit. J. exp. Path. 1953, 34, 661.

18. Tutt, M. L., Kidman, B., Rayner, B., and Vaughan, J. M. The deposition of $\mathrm{Sr}^{80}$ in rabbit bones fol- lowing intravenous injection. Brit. J. exp. Path. 1952, 33, 207.

19. Pecher, C. Biological investigations with radioactive calcium and strontium. Proc. Soc. exp. Biol. (N. Y.) 1941, 46, 86.

20. Lehnerdt, F. Zur Frage der Substitution des Calcium im Knochensystem durch Strontium. Beitr. path. Anat. 1909, 46, 468.

21. Shipley, P. G., and Park, E. A. Studies on experimental rickets. XX. The effects of strontium administration on histological structure of growing bones. Johns Hopk. Hosp. Bull. 1922, 33, 216.

22. von Hodel, E. Zur Biochemie der Erdalkalein. Helv. chim. Acta 1925, 8, 514

23. Spencer, H., Laszlo, D., and Brothers, M. Strontium $^{85}$ and calcium ${ }^{45}$ metabolism in man. J. clin. Invest. 1957, 36, 680 .

24. MacDonald, N. S., Noyes, P., and Lorick, P. C. Discrimination of calcium and strontium by the kidney. Amer. J. Physiol. 1957, 188, 131.

25. McCance, R. A., and Widdowson, E. M. The fate of strontium after intravenous administration to normal persons. Biochem. J. 1939, 33, 1822.

26. Harrison, G. E., Raymond, W. H. A., and Tretheway, H. C. The metabolism of strontium in man. Clin. Sci. 1955, 14, 681.

27. Bauer, G. C. H., Carlsson, A., and Lindquist, B. A comparative study on the metabolism of $\mathrm{Sr}^{90}$ and $\mathrm{Ca}^{45}$. Acta physiol. scand. 1955, 35, 56.

28. Bauer, G. C., and Ray, R. D. Kinetics of strontium metabolism in man. J. Bone Jt Surg. 1958, 40 A, 171.

29. Van Dilla, M. A., and Arnold, J. S. Strontium ${ }^{85}$ tracer studies in humans (abstract). Int. J. appl. Radiat. 1956, 1, 129.

30. Norris, W. P., and Kisielski, W. Comparative metabolism of radium, strontium, and calcium. Cold Spr. Harb. Symp. quant. Biol. 1948, 13, 164.

31. Thomas, R. O., Litovitz, T. A., Rubin, M., and Geschickter, C. F. Dynamics of calcium metabolism. Time distribution of intravenously administered radiocalcium. Amer. J. Physiol. 1952, 169, 568.

32. Heaney, R. P., and Whedon, G. D. Radiocalcium studies of bone formation rate in human metabolic bone disease. J. clin. Endocr. 1958, 18, 1246.

33. Albright, F., and Henneman, P. H. The suppression of Paget's disease with ACTH and cortisone. Trans. Ass. Amer. Phycns 1955, 68, 238.

34. Nordin, B. E. C. Investigation of bone metabolism with ${ }^{47} \mathrm{Ca}-\mathrm{A}$ preliminary report. Proc. roy. Soc. Med. 1959, 52, 351.

35. Gardner, W. U., and Pfeiffer, C. Skeletal changes in mice receiving estrogens. Proc. Soc. exp. Biol. (N. Y.) 1938, 37, 678.

36. Urist, M. R., Budy, A. M., and McLean, F. C. Species differences in reaction of mammalian skele- 
ton to estrogens. Proc. Soc. exp. Biol. (N. Y.) 1948, 68, 324.

37. Day, H. G., and Follis, R. H., Jr. Skeletal changes in rats receiving estradiol benzoate as indicated by histological studies and determinations of bone ash, serum calcium, and phosphatase. Endocrinology 1941, 28, 83.

38. Albright, F., Bloomberg, E., and Smith, P. H. Postmenopausal osteoporosis. Trans. Ass. Amer. Phycns 1940, 55, 298.
39. Reifenstein, E. C., Jr., and Albright, F. The metabolic effects of steroid hormones in osteoporosis. J. clin. Invest. 1947, 26, 24.

40. Blau, M., Spencer, H., Swernov, J., and Laszlo, D. Utilization and intestinal excretion of calcium in man. Science 1954, 120, 1029.

41. Bronner, F., Benda, C. E., Harris, R. S., and Kreplick, J. Calcium metabolism in a case of gargoylism, studied with the aid of radiocalcium. J. clin. Invest. 1958, 37, 139. 